\title{
Din Derslerine Giren Öğretmenlerin Yeterliklerine Dair Bir İnceleme
}

\author{
A Research about the Competency of Religion Teachers
}

\section{Umut KAYA*}

Öz: Bu araştırma, Marmara Üniversitesi İlahiyat Fakültesi’nde okuyan öğretmen adaylarının gözlemlerine göre din dersi öğretmenlerinin yeterliklerini ölçmeyi amaçlamaktadır. Bu doğrultuda 331 öğretmen adayı, 93 din dersi öğretmenini sınıf ortamında gözlemlemiştir. Öğretmenlerinin cinsiyet dağılımına baktığımızda, öğretmenlerin \%58,1 (54)'nin kadın, \% 41,9 (39)'nun ise erkek olduğu görülmektedir. Öğretmenlerin yaşlarına göre dağılımları ise şu şekildedir: 20-29 yaş (\%12,9, N=12), 30-39 yaş (\%54,8, $\mathrm{N}=51), 40-49$ yaş (\%24,7, $\mathrm{N}=23), 50-59$ yaş $(7,5 \%, \mathrm{~N}=7)$.

$\mathrm{Bu}$ çalışmada şu soruya cevap aranmıştır: Cinsiyet, yaş, okul türü ve ders işleme yöntemi değişkenleri din dersi öğretmenlerinin yeterlikleri arasında bir farklılaşma meydana getirmekte midir? Bu soruya cevap bulmak için araştırmada din dersi öğretmenlerinin öğretme-öğrenme sürecini, materyal kullanma ve öğrenci tanıma ile iletişim boyutu yeterlikleri incelenmiştir.

$\mathrm{Bu}$ doğrultuda veri toplama aracı olarak gözlem ve anket tekniği kullanılmıştır. Araştırmada kullanılan ölçek "öğrenme-öğretme", "materyal kullanma" ve "öğrenciyi tanıma ve iletişim becerisi” olmak üzere üç faktörden oluşmaktadır. Faktörlerin toplam varyansı \%47,67 olmuştur. Verilerin analizinde SPSS İstatistik programı kullanılmıştır. Araştırma problemlerin test edilmesinde Bağımsız Örneklem T Testi, Anova, Welch, LSD ve Dunnett $\mathrm{C}$ testleri kullanılmıştır. Testin yapı geçerliği ve güvenirliğini ölçmek için yapılan testte, KMO değeri 0.935; Cronbach Alfa güvenirlik değerleri (üç faktör için) 0.93, 0.87 ve 0.84 bulunmuştur.

Yapılan farklılık analizleri neticesinde ise cinsiyet, yaş, okul türü ve ders işleme yöntemi değişkenlerinin ölçeğin genel ortalamasında ya da ilgili boyutların en az birinde $\mathrm{p}<.05$ anlamlılık düzeyinde bir farklılığa sebep olduğu saptanmıştır.

Araştırma bulgularından bazıları şöyledir:

Cinsiyet değişkeni öğrenme-öğretme boyutunda istatistiksel olarak anlamlı bir farklılık oluşturmamaktadır. Bunun yanında yaş, okul türü ve ders işleme yönteminde ise bu boyutta istatistiksel açıdan anlamlı farklılık bulunmuştur. Buna göre, 50-59 yaş aralığındaki öğretmenlerin, 20-29 ve 30-39 yaş aralığındaki öğretmenlere göre; İHO’da çalışan öğretmenlerin ilkokulda çalışan öğretmelere göre; derslerini öğretmen merkezli işleyen öğretmenlerin de öğrenci merkezli işleyenlere göre bu boyutta daha fazla puan aldıkları tespit edilmiştir. Bu farklar istatistiksel olarak da anlamlıdır.

Değişken olarak çalışılan okul türü materyal kullanma boyutunda öğretmenler arasında istatistiksel olarak anlamlı bir farklılık oluşturmamaktadır. Bunun yanında cinsiyet, yaş

* Dr. Öğr. Üyesi, Marmara Üniversitesi İlahiyat Fakültesi İDKAB Bölümü, umut.kaya@marmara.edu.tr

Orcid No: 0000-0002-3237-8150 
ve ders işleme yönteminde ise bu boyutta istatistiksel açıdan anlamlı farklılık bulunmuştur. Buna göre, erkek öğretmenlerin kadın öğretmenlere göre; 40-49 yaş aralığındaki öğretmenlerin 20-29 ve 30-39 yaş aralığındaki öğretmenlere göre; benzer şekilde 50-59 yaş aralığındaki öğretmenlerin de 20-29 ve 30-39 yaş aralığındaki öğretmenlere göre; öğretmen merkezli ders işleyen öğretmenlerin de öğrenci merkezli ders işleyen öğretmenlere göre bu boyutta daha fazla puan aldıkları tespit edilmiştir. Bu farklar istatistiksel olarak da anlamlıdır.

Öğrenciyi tanıma ve iletişim becerisi boyutunda ise yaş değişkeni anlamlı bir farklılık oluşturmamaktadır. Bu boyutta, cinsiyet, okul türü ve ders işleme yöntemi değişkenleri öğretmenler arasında anlamlı farklılıklar oluşturmaktadır. Buna göre, erkek öğretmenlerin kadın öğretmenlere göre; öğretmen merkezli ders işleyen öğretmenlerin de öğrenci merkezli ders işleyen öğretmenlere göre bu boyutta daha fazla puan aldıkları tespit edilmiştir. Okul türü değişkeninde ise ilköğretimde çalışan öğretmenlerin İHO, ortaokul ve Anadolu lisesinde çalışan öğretmenlere göre daha düşük puan aldıkları saptanmıștır. Puanlar arasındaki bu farklar istatistiksel olarak da anlamlıdır.

Araştırma sonucunda, din dersi öğretmenlerinin öğrenme-öğretme boyutu aritmetik ortalamaları 2,31 (az düzeyde), materyal kullanma boyutu aritmetik ortalamaları 3,71 (oldukça düzeyinde), öğrenciyi tanıma ve iletişim becerisi boyutu aritmetik ortalamaları 2,38 (az düzeyde) çıkmıştır. Bu sonuçlar, daha önceki araştırma sonuçlarından epey düşük seviyelerdedir. Bunun sebebi öğretmenlerin kendi yeterlik algıları ile sınıf içi gözlemlenen performansları arasında fark olmasıdır. Öğretmen yeterliklerinin daha objektif şekilde tespit edilmesi için öğrenci, idareci, meslektaş ve veli görüşlerine de müracaat edilmelidir.

Anahtar Kelimeler: Din Eğitimi, Öğretmen Yeterlikleri, Öğrenme-Öğretme Süreci, Materyal Kullanma, Öğrenciyi Tanıma ve İletişim Becerisi

\section{A Research about the Competency of Religion Teachers}

Abstract: The aim of this research is to measure the competency of religion teachers according to religion teacher candidates in Marmara University Faculty of Theology. On this basis, 331 candidate teachers observed 93 religion teachers in a class environment. When looking at the gender dispersion in the religion teachers group, a distribution of the percentage of female participants is seen as $58,1 \%(\mathrm{~N}=54)$ and that of male participants is seen as $41,9 \%(\mathrm{~N}=39)$. Religion teachers' ages range between $20-29$ to $50-59$ years old as follows; $20-29$ years $(12,9 \%, \mathrm{~N}=12), 30$ - 39 years $(54,8 \%, \mathrm{~N}=51), 40-49$ years $(24,7 \%, \mathrm{~N}=23)$, and $50-59$ years $(7,5 \%, \mathrm{~N}=7)$ in this research.

This article used the survey and observation technique to collect data. The scale consists of three parts, which are learning-teaching dimension, using material dimension and recognition of students and communication skills dimension. The total variance explained by the scale is $47,67 \%$. In the analysis of the data the SPSS Statistic Programme was used. Independent Samples T-test, Anova, Welch, Dunnett C and LSD were used to test research problems. The analysis that is done for construct validity and reliability shows the value of KMO is 0.935 and Cronbach Alfa are $0.93,0.87$ and 0.84 for three factors.

In this study, the following questions are explored: How do the gender, age, school type and method of lesson processing variables make difference in the level of meaning in the competences of the religion teacher's. In order to find the appropriate answers to these questions, religion teacher's capabilities related to learning-teaching dimension, using 
material dimension and recognition of students and communication skills dimension were examined.

The results of the analyses, which are conducted to examine differences between the various groups, reveal that gender, age, school type and method of lesson processing cause statistically significant differences at $\mathrm{p}<0,05$ significant level whether on the general average of the scale or one of the sub-dimensions at least.

Some of the research findings are as follows:

The gender variable is not statistically significant in the learning-teaching dimension. Moreover, there is a meaningful difference between the ages, school types, methods of lesson processing in this dimension. 50-59 years old religion teachers $(x=50,60)$ scored higher than 20-29 ( $x=42,50)$ and 30-39 $(x=42,60)$ years old religion teachers. Teachers working in İHO $(x=47,16)$ scored higher than teachers working in primary education $(x=36,92)$. Teacher-centered teachers $(x=46,30)$ scored higher in this dimension as opposed to the student-centered teachers $(x=36,27)$. These differences are statistically significant.

The school type variable is not statistically significant in the using of the material dimension. Furthermore, there is a meaningful difference between the gender, ages, and methods of lesson processing in this dimension. Male teachers $(x=54,60)$ scored higher in the using of material dimension as opposed to the female teachers $(x=50,68)$. The 40 49 years old religion teachers $(x=54,26)$ scored higher than the 20-29 $(x=48,19)$ and the $30-39(x=51,13)$ years old religion teachers. Similarly, the 50-59 years old religion teachers $(x=58,40)$ scored higher than the 20-29 $(x=48,19)$ and the 30-39 $(x=51,13)$ years old religion teachers. The teacher-centered teachers $(x=53,75)$ scored higher in this dimension as opposed to the student-centered teachers $(\mathrm{x}=46,56)$. These differences are statistically significant.

On the other hand, age variable is not statistically significant in the recognition of students and communication skills dimension. Moreover, there is a meaningful difference between the gender, school type and methods of lesson processing in this dimension.

The male teachers $(x=20,25)$ scored higher in the using of material dimension as opposed to the female teachers $(x=18,44)$. The teachers working in primary education $(x=15,78)$ scored lower than the teachers working in İHO $(x=20,50)$, the secondary school $(x=19,71)$, and the Anatolian high school $(x=17,72)$. The teacher-centered teachers $(x=20,07)$ scored higher in this dimension as opposed to the student-centered teachers $(\mathrm{x}=15,84)$. These differences are statistically significant.

According to the above results, the religion teacher's learning-teaching dimension arithmetic mean is 2,31 (insufficient level); using of the material dimension arithmetic mean is 3,71 (good level) and the recognition of students and communication skills dimension arithmetic mean is 2,38 (insufficient level). These results are lower from the previous studies conducted. The reason for this is the difference between the teachers' self-competence and capability perceptions and their observed classroom performances. For further and more objective detection of teacher competency such a research should be conducted on opinions of student, manager, colleague and parent.

Keywords: Religious Education, Teacher Competence, Learning-Teaching Process, Using Material, Recognition of Students and Communication Skill 


\section{Giriş}

Eğitimin kalitesi ve hedeflere ulaşma oranı her dönemde tartışılan konulardan birisidir. Şüphesiz eğitimde istenilen sonuçlara ulaşmayı sağlayan en önemli faktörlerden birisi öğretmenlerdir. Öğretmenlerin mesleklerinin gerektirmiş olduğu yeterliklere sahip olma düzeyleri, eğitimin niteliği ve hedeflere ulaşma düzeyi ile yakından ilgilidir. Öğretmenlik, devletin eğitim programını uygulayan, yakın ve uzak hedeflere ulaşılmasını sağlayan, devletin eğitim felsefesini hayata geçiren bir meslektir. Tüm bunların ancak mesleğinde yetkin ve aranılan yeterliklere sahip bir öğretmenin elinde gerçekleşeceği çok açıktır. Bu sebeple 1789 sayılı Milli Eğitim Temel Kanunu'nun 43. maddesinde öğretmenlik, "Genel kültür, özel alan, eğitim ve pedagojik formasyonla sağlanan özel bir ihtisas mesleği” olarak tanımlanmıştır. ${ }^{1}$

Yeterlik, "bir işi etkili ve verimli biçimde yerine getirebilmek için sahip olunması gereken bilgi, beceri, tutum ve değerler" olarak tarif edilmektedir. Bu açıdan öğretmen yeterliklerin belirlenmesine yönelik ülkemizde son yirmi yılda ciddi çalışmalar yapılmış ve öğretmenlerden beklenen yeterliklerin neler olması gerektiği açıklanmıştır.

Ülkemizde öğretmenlik mesleğindeki temel yeterlik alanların belirlenmesine yönelik ilk çalışma 1998-1999 yıllarında YÖK ve Dünya Bankası ortak çalışması ile başlatılmış ve bu doğrultuda öğretmenlik mesleğinin yeterlikleri "Konu Alanı ve Alan Eğitimine İlişkin Yeterlikler”, “Öğrenme-Öğretme Sürecine İlişkin Yeterlikler”, “Öğrencilerin Öğrenmelerini İzleme, Değerlendirme ve Kayıt Tutma” ve “Tamamlayıcı (Diğer) Mesleki Yeterlikler” olmak üzere dört başlık altında toplanmıştır.

Bu sürecin hemen akabinde ise, Millî Eğitim Bakanlığı 1999 yılında öğretmen yeterlikleri ile ilgili olarak Milli Eğitim Bakanlığı ve üniversite temsilcilerinden oluşan "Öğretmen Yeterlikleri Komisyonu”nu kurarak çalışmalara başlamıştır. Bu komisyonun çalışmaları sonucunda, 2002 yılında öğretmen yeterlikleri "Eğitme-Öğretme Yeterlikleri”, "Genel Kültür Bilgi ve Becerileri”, “Özel Alan Bilgi ve Becerileri” olmak üzere üç başlık altında toplanarak gerekli düzenlemelerin yapılabilmesi için ilgili yükseköğretim kurumlarına gönderilmiştir.

Öğretmen yeterliklerin belirlenmesine yönelik bir başka çalışma ise 13-16 Nisan 2004 tarihinde gerçekleştirilen bir çalıştay kapsamında gerçekleştirilmiştir. Avrupa Birliği ile uyum çalışmaları dikkate alınarak gerçekleştirilen çalıştay sonucunda öğretmen yeterlikleri, "Kişisel ve Mesleki Değerler”, “Öğrenme-Öğretme Süreci”, “Öğrenciyi Tanıma”, “Öğrenmeyi, Gelişimi İzleme ve Değerlendirme”, "Program ve İçerik Bilgisi”, "Okul, Aile ve Toplum İlişkileri” olmak üzere 6 başlık altında toplanmıştır. Aynı şekilde bu doğrultuda bu yeterlik alanları ile ilgili 31 alt yeterlik ve 233 performans göstergesi “Öğretmenlik Mesleği Genel Yeterlikleri Taslağı”nda ortaya konulmuştur. Daha sonra taslağa son şekli verilerek 2006 yılında Tebliğler Dergisinde yayınlanarak yürürlüğe girmesi sağlanmıştır. ${ }^{2}$

1 Milli Eğitim Temel Kanunu, Md 43.

2 Milli Eğitim Bakanlı̆̆ı Tebliğler Dergisi, Kasım 2006-2590, Ankara, s. 1491-1540. 
“Öğretmenlik Mesleği Genel Yeterlik”lerinin belirlenmesinden sonra, branşlara yönelik özel alan yeterliklerinin belirlenmesine yönelik çalışmalara başlanılmıştır. Bu doğrultuda ilköğretime yönelik Beden Eğitimi, Bilişim Teknolojileri, Din Kültürü ve Ahlak Bilgisi, İngilizce, Görsel Sanatlar, Fen ve Teknoloji, Türkçe, Matematik, Müzik, Okul Öncesi, Sınıf Öğretmenliği, Sosyal Bilgiler, Teknoloji Tasarım, Özel Eğitim branşları ile ilgili özel alan yeterlikleri 2008 yılında; ortaöğretime yönelik Biyoloji, Coğrafya, Felsefe, Fizik, Kimya, Matematik, Tarih, Türk Dili ve Edebiyatı ile ilgili özel alan yeterlikleri ise 2011 yılında yayınlanmıştır.

Ülkemizde öğretmenlik mesleğinin yeterlikleri ile ilgili son çalışma ise Milli Eğitim Bakanlığı Öğretmen Yetiştirme ve Geliştirme Genel Müdürlüğü tarafından 2017 yılında yayınlanmıştır. Dünyada eğitim alanında yaşanan yeniliklere ve gelişmelere uyum sağlamak adına farklı ülkelerdeki öğretmen yeterlikleri incelenerek yapılan çalışmada, yurt içinden de birçok paydaşla iş birliği gerçekleştirilmiştir. Buna göre, son düzenlemede öğretmenlik mesleği genel yeterlik alanlarının sadeleştirildiği ve genel yeterlik ile özel alan bilgisi yeterliklerinin birleştirilerek tek bir metin oluşturulduğu görülmektedir. Bu doğrultuda yenilenen Öğretmenlik Mesleği Genel Yeterlikleri, "mesleki bilgi", "mesleki beceri", "tutum ve değerler" olmak üzere 3 ana yeterlik alanı altında ele alınmıştır. Metinde ayrıca bu 3 yeterlik alanının altında 11 alt yeterlik başlığ 1 ve bunlara ilişkin 65 gösterge yer almaktadır. ${ }^{3}$ Buna göre oluşturulan 3 yeterlik alanı ve 11 alt yeterlik alanı aşağıdaki gibidir:

\begin{tabular}{|l|l|l|}
\hline Mesleki Bilgi & Mesleki Beceri & Tutum ve Değerler \\
\hline Alan Bilgisi & Eğitim ve Öğretimi Planlama & Milli, Manevi ve Evrensel Değerler \\
\hline Alan Ĕ̆itimi Bilgisi & Öğrenme Ortamları Oluşturma & Öğrenciye Yaklaşım \\
\hline Mevzuat Bilgisi & Öğretme ve Öğrenme Sürecini Yönetme & İletişim ve İş Birliği \\
\hline & Ölçme ve Değerlendirme & Kişisel ve Mesleki Gelişim \\
\hline
\end{tabular}

\section{Araştırmanın Problemi, Önemi ve Amacı}

Genel olarak öğretmen yeterlikleri, özel olarak ise din derslerine giren öğretmenlerin yeterlikleri ile ilgili bugüne kadar pek çok araştırma yapılmış ve yayınlanmıştır. Bu çalışmaların hepsini burada zikretmek çalışmanın sınırlarını aşacaktır. Ancak bu araştırmada sonuçların karşılaştırılabilmesi için YÖK'ün "tez tarama” ve İSAM Kütüphanesi’nin makale ve eser arama sayfalarından "yeterlik" ve "yeterlilik" anahtar kelimeleri ile yapilan arama sonucunda konu ile ilgili tespit edilebilen eserler daha sonraki çalışmalara yol göstermesi bakımından kaynakçada gösterilmiştir.

Bununla beraber bu çalışmalardan M. Şevki Aydın’n (1992-Dr) Din Kültürü ve Ahlak Bilgisi Öğretmenlerinin Pedagojik Formasyon Yeterlikleri, Suat Cebecỉnin (1994-Dr) 
İmam-Hatip Lisesi Meslek Dersleri Öğretmenlerinin Yeterlilikleri isimli doktora tezleri ile Recai Doğan-Nurullah Altaş 2002 ve 2003 yıllarında yayınlamış oldukları "İlköğretim Din Kültürü ve Ahlak Bilgisi Öğretmenlerinin Yeterlik Ölçeği Üzerine Bir Ön Araştırma” ile “İlköğgretim Din Kültürü ve Ahlak Bilgisi Öğretmenlerinin Yeterlik Düzeyini Belirleyen Faktörler (Ankara Örneği)" isimli makaleleri, bu alandaki çalışmaların ilkleri olarak zikretmek yerinde olacaktır. ${ }^{4}$

Söz konusu çalışmalar içinde alan araştırması niteliğinde olan çalışmalarda, öğretmen yeterlikleri ile ilgili tespitler bizzat öğretmenin öz değerlendirmeleri üzerinden yapılmıştır. $\mathrm{Bu}$ araştırmada ise anket soruları öğretmenlerin bizzat kendilerine değil, okul deneyimi ve öğretmenlik uygulaması derslerinde ders öğretmenlerini gözlemleyen öğretmen adaylarına sorulmuştur. Gözlem tekniğinin bu türüne ikinci elden gözlem denilmektedir. Araştırma, bu özelliği ile öğretmen yeterliklerini değerlendiren önceki araştırmalardan ayrılmaktadır. Araştırmada gözleme dayandığından ölçme aracındaki sorular, yeterliklerle ilgili gözlem yapılarak cevap verilebilecek şekilde tasarlanmıştır.

Araştırma, örgün eğitim sisteminde yer alan zorunlu Din Kültürü ve Ahlak Bilgisi, seçmeli din dersleri ve İmam Hatip Ortaokul ve Liselerindeki meslek derslerine giren öğretmenlerin yeterlik düzeylerini ve bu düzeyler arasında çeşitli değişkenler açısından farklılaşmaları belirlemeyi amaçlamaktadır. Araştırmanın alt amaçları ise şu şekildedir:

Din dersi öğretmenlerinin;

1. Öğrenme-öğretme sürecini yönetme,

2. Öğretim materyallerini kullanma,

3. Öğrenciyi tanıma ve iletişim boyutlarındaki yeterliklere sahip olma düzeylerinin, cinsiyet, yaş, görev yapılan okul türü ve ders işleme yöntemi değişkenleri açısından anlamlı bir farklılaşma gösterip göstermediğini belirlemektir.

\section{Araştırmanın Sınırlıkları ve Yöntemi}

Araştırmada kullanılan veriler, 2016-2017 öğretim yılında Marmara Üniversitesi İlahiyat Fakültesi İDKAB ve İlahiyat Bölümü’nde öğretmenlik uygulaması dersini alan 331 öğretmen adayının, İstanbul'un Üsküdar, Kadıköy ve Ümraniye ilçelerinde gitmiş oldukları staj okullarındaki 93 din dersi öğretmenine yapmış oldukları gözlemlerle sınırlıdır.

4 Muhammed Şevki Aydın, Din Kültürü ve Ahlak Bilgisi Öğretmenlerinin Pedagojik Formasyon Yeterlikleri (doktora tezi, 1992), Erciyes Üniversitesi; Suat Cebeci, İmam-Hatip Lisesi Meslek Dersleri Öğretmenlerinin Yeterlilikleri (doktora tezi, 1994), Ankara Üniversitesi; Recai Doğan - Nurullah Altaş, "İlköğretim Din Kültürü ve Ahlak Bilgisi Öğretmenlerinin Yeterlik Düzeyini Belirleyen Faktörler (Ankara Örneği)", Ankara Üniversitesi İlahiyat Fakültesi Dergisi, XLIV/2, 2003; Recai Doğan - Nurullah Altaş, "İlköğretim Din Kültürü ve Ahlak Bilgisi Öğretmenlerinin Yeterlik Ölçeği Üzerine Bir Ön Araştırma”, Ankara Üniversitesi İlahiyat Fakültesi Dergisi, XLIII/1, 2002. 
Aday öğretmenler bir öğretmeni 2 ile 10 ders arasında gözlemlemişlerdir. Öğretmen adaylarının yapmış oldukları gözlem ortalamalarına bakıldığında her öğretmen adayının ortalama 7,5 ders saati gözlem yaptığı görülmektedir.

Gözlemi yapan 331 öğretmen adayından, 129'u Marmara Üniversitesi İlahiyat Fakültesi İlköğretim Din Kültürü ve Ahlak Bilgisi Öğretmenliği Bölümü, 211’i ise aynı fakültenin İlahiyat Fakültesi pedagojik formasyon sertifika programında yer alan öğrencilerdir.

Gözlemlenen 93 öğretmenin cinsiyetleri, yaşları, görev yapmış olduğu okul türleri ile ilgili tablolar ise şu şekildedir:

Tablo 1: Gözlem Yapılan Okul Türleri

\begin{tabular}{|l|l|l|}
\hline Okul Türleri & Sayı & Yüzde \\
\hline İlkokul & 6 & $\% 6,5$ \\
\hline Ortaokul & 34 & $\% 36,6$ \\
\hline İmam Hatip Ortaokul & 13 & $\% 14,0$ \\
\hline Anadolu İHL & 21 & $\% 22,6$ \\
\hline Meslek Lisesi & 13 & $\% 14,0$ \\
\hline Anadolu Lisesi & 5 & $\% 5,4$ \\
\hline Spor Lisesi & 1 & $\% 1,1$ \\
\hline Toplam & 93 & $\% 100$ \\
\hline
\end{tabular}

Tablo 2: Gözlemlenen Öğretmenlerin Cinsiyete Göre Dağılımları

\begin{tabular}{|l|l|l|}
\hline Cinsiyet & Sayı & Yüzde \\
\hline Erkek & 39 & $\% 41,9$ \\
\hline Kadın & 54 & $\% 58,1$ \\
\hline Toplam & 93 & $\% 100$ \\
\hline
\end{tabular}

Tablo 3: Gözlemlenen Öğretmenlerin Yaşlarına Göre Dağılımları

\begin{tabular}{|l|l|l|}
\hline Yaş & Sayı & Yüzde \\
\hline $\mathbf{2 0 - 2 9}$ & 12 & $\% 12,9$ \\
\hline $\mathbf{3 0 - 3 9}$ & 51 & $\% 54,8$ \\
\hline $\mathbf{4 0 - 4 9}$ & 23 & $\% 24,7$ \\
\hline $\mathbf{5 0 - 5 9}$ & 7 & $\% 7,5$ \\
\hline Toplam & 93 & $\% 100$ \\
\hline
\end{tabular}


Araştırmada gözlemciler 52 sorudan oluşan öğretmen yeterlik ölçeği ve kişisel bilgiler sorularından oluşan bir ölçme aracı kullanmışlardır. Ölçek hazırlanırken, bu alandaki Erten Gökçe ${ }^{5}$, Recai Doğan-Nurullah Altaş ${ }^{6}$ ve son olarak Ahmet Koç un ${ }^{7}$ konu ile ilgili çalışmalarında geliştirmiş oldukları ölçeklerden faydalanılmıştır.

$\mathrm{Bu}$ doğrultuda araştırmadan elde edilen veriler SPSS programı kullanılarak analiz edilmiştir. Öncelikle ölçeğin geçerlik ve güvenirlik çalışmaları yapılarak 0,40 ve üzeri faktör yüküne sahip, 52 soru ve 3 boyuttan oluşan yeni bir anket hazırlanmıştır. Yeniden adlandırılan bu üç boyutun açıkladığı toplam varyans ise $\% 47,67$ olmuştur.

\section{Verilerin Toplanması ve Çözümlenmesi}

Verilerin toplanması için anket tekniğinden faydalanılmış, bu doğrultuda elde edilen veriler SPSS programına aktarılarak öncelikle hatalı veri girişi olup olmadığı kontrol edilmiştir. Daha sonra ise SPSS programında gerekli analizler yapılmıştır.

$\mathrm{Bu}$ doğrultuda, toplanan verilerle öncelikle faktör analizi ${ }^{8}$ yapabilmenin ön şartı olarak kabul edilen Kaiser-Meyer-Olkin (KMO Testi) (Örneklem Yeterlik İstatistiği) ile Barlett's Test of Sphericity (Barlett Küresellik Testi) sonuçlarına bakılmıştır. Barlett testi, değişkenler arasında yeterli oranda bir ilişki olup olmadığını; KMO testi ise değişkenler arası korelasyonların faktör analizine uygun olup olmadığını göstermektedir. Bu testlerin sonuçları aşağldaki gibidir:

Tablo 4: KMO Testi Değerleri

\begin{tabular}{|l|l|}
\hline Kaiser-Meyer Olkin (KMO) Örneklem Uygunluğu Ölçüsüi & $\mathbf{0 , 9 3 5}$ \\
\hline Barlett Küresellik Testi Yaklaşık Ki Kare Değeri & 7386,649480 \\
\hline Serbestlik Derecesi (sd) & 820 \\
\hline Anlamlılık Değeri (sig) (p değeri) & 0,000 \\
\hline
\end{tabular}

5 Erten Gökçe, İlköğretim Öğretmenlerinin Yeterlikleri (doktora tezi, 2006), Ankara Üniversitesi Sosyal Bilimler Enstitüsü.

6 Recai Doğan - Nurullah Altaş, "İlköğretim Din Kültürü ve Ahlak Bilgisi Öğretmenlerinin Yeterlik Düzeyini Belirleyen Faktörler (Ankara Örneği)”, Ankara Üniversitesi İlahiyat Fakültesi Dergisi, XLIV/2, 2003.

7 Ahmet Koç, "Din Kültürü ve Ahlak Bilgisi Öğretmenlerinin Yeterlikleri”, Değerler Eğitimi Dergisi, 8/19, Haziran 2010; Ahmet Koç, "Din Kültürü ve Ahlak Bilgisi Öğretmenlerinin Öğretme-Öğrenme Sürecine İlişkin Yeterlikleri”, Türkiye’de Okullarda Din Öğretimi (ed. Recep Kaymakcan, Mahmut Zengin, Z. Şeyma Arslan), İstanbul: DEM Yayınları, 2011.

8 Faktör analizi, sosyal bilimlerde ölçek geliştirmede ve ölçeğin yapı geçerliğini test etmek amacıyla kullanılan bir analizdir. Bk. Şener Büyüköztürk, Sosyal Bilimler İçin Veri Analizi El Kitabı, Ankara: Pegem Akademi, 2017, s. 137. 
Kullanılan ölçeğin KMO değeri, 0,935, Barlett test değeri, 7386,64'dir. Bu değerler ölçeğin faktör analizi için mükemmel seviyede ${ }^{9}$ olduğunu ifade etmektedir. Aynı şekilde elde edilen bu değerler, ölçeğin faktör analizi yapılmasına uygun ve ölçülmek isteneni ölçmek için kullanışlı olduğunu göstermektedir.

Araştırmada, ikili gruplar arasında farklılaşma olup olmadığının test edilmesinde örneklem bağımsız t-testi, ikiden fazla grup arasında farklılık olup olmadığının test edilmesinde tek yönlü varyans analizi (anova) ve anova testinin yapılmasının uygun olmadığı durumlarda ise Welch testi kullanılmıştır. Anlamlı ilişki görünen durumlarda farklılı̆̆ın kaynağını tespit edebilmek için ise LSD ve Dunnett C testlerinden faydalanılmıştır. Hipotezlerin test edilmesinde ise 0,05 anlamlılık düzeyi esas alınmıştır.

Gözlemlenen öğretmenlerin belirlenen yeterliklere sahip olma düzeylerine ilişkin veriler gözlem sonuçlarına göre 5’li likert derecelendirme ölçeğiyle toplanmıştır. Gözlemlenen öğretmenlerin yeterliklere sahip olma düzeyleri ise aşağıdaki tabloda gösterilen puan sınırları dikkate alınarak yapılmıştır.

Tablo 5: Değerlendirmede Kullanılan 5’li Derecelendirme Ölçeği ve Puan Sınırı

\begin{tabular}{|l|l|l|}
\hline Derece/ Seçenek & Değer & Puan Sınırı \\
\hline Hiç & 1 & $1.00-1.79$ \\
\hline Az & 2 & $1.80-2.59$ \\
\hline Orta & 3 & $2.60-3.39$ \\
\hline Oldukça & 4 & $3.40-4.19$ \\
\hline Tam & 5 & $4.20-5.00$ \\
\hline
\end{tabular}

Toplanan veriler doğrultusunda, 52 sorudan oluşan anketin geçerliğini ortaya çıkarmak için faktör analizine tabi tutulduğunda SPSS programı soruları 9 faktöre ayırmıştır. Millî Eğitim Bakanlığı Öğretmen Yetiştirme ve Eğitimi Genel Müdürlüğü tarafından açıklanan “öğretmen yeterlikleri” merkeze alınarak yapılan değerlendirmede ise anket soruları üç faktörde birleştirilerek ele alınmıştır. Yapılan faktör analizinde faktör yük değerleri 0,40’ın altında bulunan ve değerleri negatif çıkan sorular ile her iki faktörde birden değer alıp iki faktör arasındaki fark 0,10 'dan küçük olan sorular analizden çıkartılmıştır. ${ }^{10}$ Bu doğrultuda ilk analizde 3, $10,20,21,23,33,40,46$ ve 50. sorular analizden çıkartılmıs, bu sorular çıkartıldıktan sonra yapılan ikinci analizde ise 41 ve 42 . sorular analizden çıkartılarak boyutlara son şekli verilmiştir. Çıkartılan sorular ve analiz değerleri şu şekildedir:

9 Kaynaklarda KMO değeri için 0,80 ve yukarı için mükemmel; $0,70-0,80$ arası iyi; $0,60-0,70$ arası orta; $0,50-0,60$ arası kötü; 0,50'den aşağısı değerler için ise kabul edilemez denilmiştir. Bk. Beril Durmuş -Murat Çinko - E. Serra Yurtkoru, Sosyal Bilimlerde SPSS'le Veri Analizi, İstanbul: Beta Yayınları, 2016, s. 80.

10 Kaynaklarda binişik maddelerin farklı faktörlerde sergiledikleri ilişki düzeyleri arasındaki farkın 0,1'den az olması durumunda sorunun analizden çıkartılması tavsiye edilmektedir. Bk. Büyüköztürk, Sosyal Bilimler İçin Veri Analizi El Kitabl, s. 135; Abdullah Can, SPSS ile Bilimsel Araștırma Sürecinde Nicel Veri Analizi, Ankara: Pegem Akademi, 2016, s. 329. 
Tablo 6: Analiz Sonucu Değerlendirmeye Alınmayan Sorular ve Değerleri

\begin{tabular}{|c|c|c|}
\hline Soru No & Soru & Değerler \\
\hline 33 & Öğrencilerinin dersi kaynatmasına izin veriyor mu? & $-0,521$ \\
\hline 40 & Öğrenci girişimlerini destekleyip, bunları dikkate alıyor mu? & $\begin{array}{l}\text { Birinci faktör puanı }=0,528 \\
\text { Üçüncü faktör puanı }=0,514\end{array}$ \\
\hline 46 & $\begin{array}{l}\text { Öğrencilerden gelen geribildirimleri dikkatle izleyip buna göre gerekli } \\
\text { girişimleri yapıyor mu? }\end{array}$ & $\begin{array}{l}\text { Birinci faktör puanı }=0,512 \\
\text { Üçüncü faktör puanı }=0,502\end{array}$ \\
\hline 20 & Disiplin ve motivasyonu sağlamak için ödüle başvuruyor mu? & 0,381 \\
\hline 21 & Öğrencilere uygun ödev ve sorumluluklar veriyor mu? & 0,367 \\
\hline 23 & Öğrencilerin bireysel farklılıklarını göz önünde bulunduruyor mu? & $\begin{array}{l}\text { Birinci faktör puanı }=0,487 \\
\text { Üçüncü faktör puanı }=0,412\end{array}$ \\
\hline 10 & Derslerde Kur’an-1 Kerim meali kullanıyor mu? & 0,324 \\
\hline 3 & Dersten önce, dersi işleyiş süreciyle ilgili ciddi bir planlama yapıyor mu? & $\begin{array}{l}\text { Birinci faktör puanı }=0,398 \\
\text { Üçüncü faktör puanı }=0,401\end{array}$ \\
\hline 50 & Öğrencilerin yanlış davranışlarını gördüğünde hemen tepki gösteriyor mu? & 0,137 \\
\hline 41 & Öğrenciler hocanın derslerine ilgi ve merak duyuyorlar mı? & $\begin{array}{l}\text { Birinci faktör puanı }=0,569 \\
\text { Üçüncü faktör puanı }=0,473\end{array}$ \\
\hline 42 & Öğrencilerin değer, tutum ve eğilimlerini dikkate alıyor mu? & $\begin{array}{l}\text { İkinci faktör puanı }=0,569 \\
\text { Üçüncü faktör puanı }=0,493\end{array}$ \\
\hline
\end{tabular}

Yukarıdaki sorular çıkartıldıktan sonra yapılan faktör analizi sonucunda ortaya çıkan Döndürülmüş Bileşen Matrisi (Rotated Companent Matrix) sonuçları aşağıdaki Tablo 7'de verilmiştir. Aşağıdaki tablodan da görüleceği üzere analizden üç boyutlu bir yapı çıkmıştır. Sözü edilen tablo şu şekildedir:

Tablo 7: Döndürülmüş Bileşen Matrisi Değerleri (Rotated Companent Matrix)

\begin{tabular}{|c|c|c|c|}
\hline \multicolumn{4}{|c|}{ Döndürülmüş Bileşen Matrisi Değerleri } \\
\hline Soru No & 1 & 2 & \\
\hline 32 &, 753 & & \\
\hline 25 &, 733 & & \\
\hline 26 &, 728 & & \\
\hline 35 &, 723 & & \\
\hline 4 &, 676 & & \\
\hline 27 &, 673 & & \\
\hline 30 &, 665 & & \\
\hline 5 &, 660 & & \\
\hline 22 &, 657 & & \\
\hline 29 &, 632 & & \\
\hline 28 &, 618 & & \\
\hline 31 &, 606 & & \\
\hline 34 &, 593 & & \\
\hline & & \\
\hline
\end{tabular}




\begin{tabular}{|c|c|c|c|}
\hline 36 & ,583 & & \\
\hline 9 & ,580 & & \\
\hline 39 & ,579 & & \\
\hline 6 & ,569 & & \\
\hline 8 & ,528 & & \\
\hline 2 & ,484 & & \\
\hline 15 & & 739, & \\
\hline 16 & & ,715 & \\
\hline 17 & & ,689 & \\
\hline 18 & & ,673 & \\
\hline 14 & & ,661 & \\
\hline 37 & & ,642 & \\
\hline 13 & & ,606 & \\
\hline 19 & & ,569 & \\
\hline 51 & & ,566 & \\
\hline 49 & & ,536 & \\
\hline 12 & & ,522 & \\
\hline 1 & & 445 & \\
\hline 7 & & ,426 & \\
\hline 11 & & ,423 & \\
\hline 47 & & & ,712 \\
\hline 43 & ,417 & & ,660 \\
\hline 52 & & & 657 \\
\hline 48 & ,415 & & ,626 \\
\hline 44 & & & ,603 \\
\hline 38 & & & ,593 \\
\hline 45 & & & ,539 \\
\hline 24 & & & ,486 \\
\hline
\end{tabular}

Buna göre, teorik olarak da bir temel boyut altında yer alabileceği düşünülen maddeler isimlendirilmiş ve her bir alt boyuta ait analiz sonuçları aşağıdaki tablolarda sunulmuştur.

Tablo 8: Boyutların Toplam Varyans Değerleri

\begin{tabular}{|c|c|c|c|c|c|c|}
\hline \multirow{2}{*}{ Faktörler } & \multicolumn{3}{|c|}{$\begin{array}{c}\text { (Initial Eigenvalues) } \\
\text { Başlangıç Öz Değerleri }\end{array}$} & \multicolumn{2}{c|}{$\begin{array}{c}\text { (Rotation Sums of Squared Loadings) } \\
\text { Döndürülmüs Kareli Yüklerin Toplamı }\end{array}$} \\
\cline { 2 - 7 } & Toplam & $\begin{array}{c}\text { Açıllanan } \\
\text { Varyans } \\
\text { Yüzdeliği }\end{array}$ & $\begin{array}{c}\text { Açıllanan } \\
\text { Yığmalı Varyans } \\
\text { Yüizdeliği }\end{array}$ & Toplam & $\begin{array}{c}\text { Açıllanan } \\
\text { Varyans } \\
\text { Yüzdeliği }\end{array}$ & $\begin{array}{c}\text { Açılkanan } \\
\text { Yığmalı Varyans } \\
\text { Yüzdeliği }\end{array}$ \\
\hline $\begin{array}{c}\text { Öğrenme-Öğretme } \\
\text { Süreci }\end{array}$ & 14,013 & 34,178 & 34,178 & 9,093 & 22,178 & 22,178 \\
\hline $\begin{array}{c}\text { Materyal Kullanma } \\
\text { Öğrenciyi Tanıma ve } \\
\text { İletişim }\end{array}$ & 3,743 & 9,130 & 43,309 & 5,778 & 14,094 & 36,272 \\
\hline
\end{tabular}


Tablo 9/A: Öğrenme-Öğretme Süreci Boyutu Geçerlik ve Güvenirlik Analizi Sonuçları

\begin{tabular}{|c|c|c|c|c|}
\hline Boyut & \multicolumn{2}{|r|}{ Yeterlikler } & \multirow{2}{*}{$\begin{array}{c}\begin{array}{c}\text { Faktör } \\
\text { yük } \\
\text { değeri }\end{array} \\
, 753\end{array}$} & \multirow{2}{*}{$\begin{array}{c}\begin{array}{c}\text { Madde } \\
\text { Toplam } \\
\text { Korelasyonu }\end{array} \\
, 549\end{array}$} \\
\hline \multirow{19}{*}{ 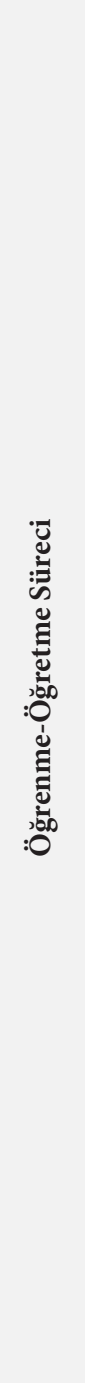 } & 32 & Derste sesini etkili kullanabiliyor mu? & & \\
\hline & 25 & İletişimde sözel dili anlaşılır ve etkili biçimde kullanıyor mu? & ,733 & ,687 \\
\hline & 26 & Derslere giriş-çıkışlarda ve ders süresince zamanı etkin kullanıyor mu? & ,728 & 677 \\
\hline & 35 & Ders işlerken öğrencilerin konuyla ilgili ön bilgilerini dikkate alıyor mu? & ,723 & ,738 \\
\hline & 4 & Ders işlerken konuyu önceki ve sonraki konularla ilişkilendiriyor mu? & ,676 & ,694 \\
\hline & 27 & Öğrencilerin sorularına uygun ve yeterli cevaplar veriyor mu? & ,673 & ,668 \\
\hline & 30 & İletişimde beden dilini etkili kullanıyor mu? & ,665 & ,738 \\
\hline & 5 & Ders konularını günlük hayatla ilişkilendiriyor mu? & ,660 & ,621 \\
\hline & 22 & $\begin{array}{l}\text { Dini kavramları ögrencilerin seviyesine göre açık ve anlaşılır biçimde } \\
\text { sunuyor mu? }\end{array}$ & ,657 &, 594 \\
\hline & 29 & $\begin{array}{l}\text { Sınıf içinde tüm öğrencilerin sürece katılımını sağlayacak etkili bir } \\
\text { iletişim ortamı oluşturabiliyor mu? }\end{array}$ & ,632 & ,691 \\
\hline & 28 & Öğrencilerle göz iletişimi kuruyor mu? &, 618 &, 590 \\
\hline & 31 & Öğrencilerde dinle ilgili araştırma, soru sorma isteği uyandırıyor mu? & ,606 & ,655 \\
\hline & 34 & $\begin{array}{l}\text { Derse girdiğinde fiziki veya psikolojik açıdan sınıf atmosferine dikkat } \\
\text { edip, duruma göre gerekli girişimlerde bulunuyor mu? }\end{array}$ &, 593 & 411 \\
\hline & 36 & $\begin{array}{l}\text { Ders işlerken, öğrencileri düşünmeye sevk eden, anlamlı ve derinliği } \\
\text { olan sorular soruyor mu? }\end{array}$ &, 583 &, 524 \\
\hline & 9 & Dersin sonunda bir özet ve değerlendirme yapıyor mu? &, 580 & ,647 \\
\hline & 39 & Sınıf içi etkileşimde disiplin ve kontrolü sağlayabiliyor mu? &, 579 & ,441 \\
\hline & 6 & Ders işlerken ara özet yapıyor mu? &, 569 & ,600 \\
\hline & 8 & Dersin sonunda öğrenilenleri kontrol edip, gerekli düzeltmeleri yapıyor mu? &, 528 & ,617 \\
\hline & 2 & $\begin{array}{l}\text { Derse giriş yaparken ögrrencilerin derse motive olmasını sağlayacak } \\
\text { güdüleme ve hedeften haberdar etme etkinliklerini yapıyor mu? }\end{array}$ & ,484 & ,606 \\
\hline
\end{tabular}


Tablo 9/B: Materyal Kullanma Boyutu Geçerlik ve Güvenirlik Analizi Sonuçları

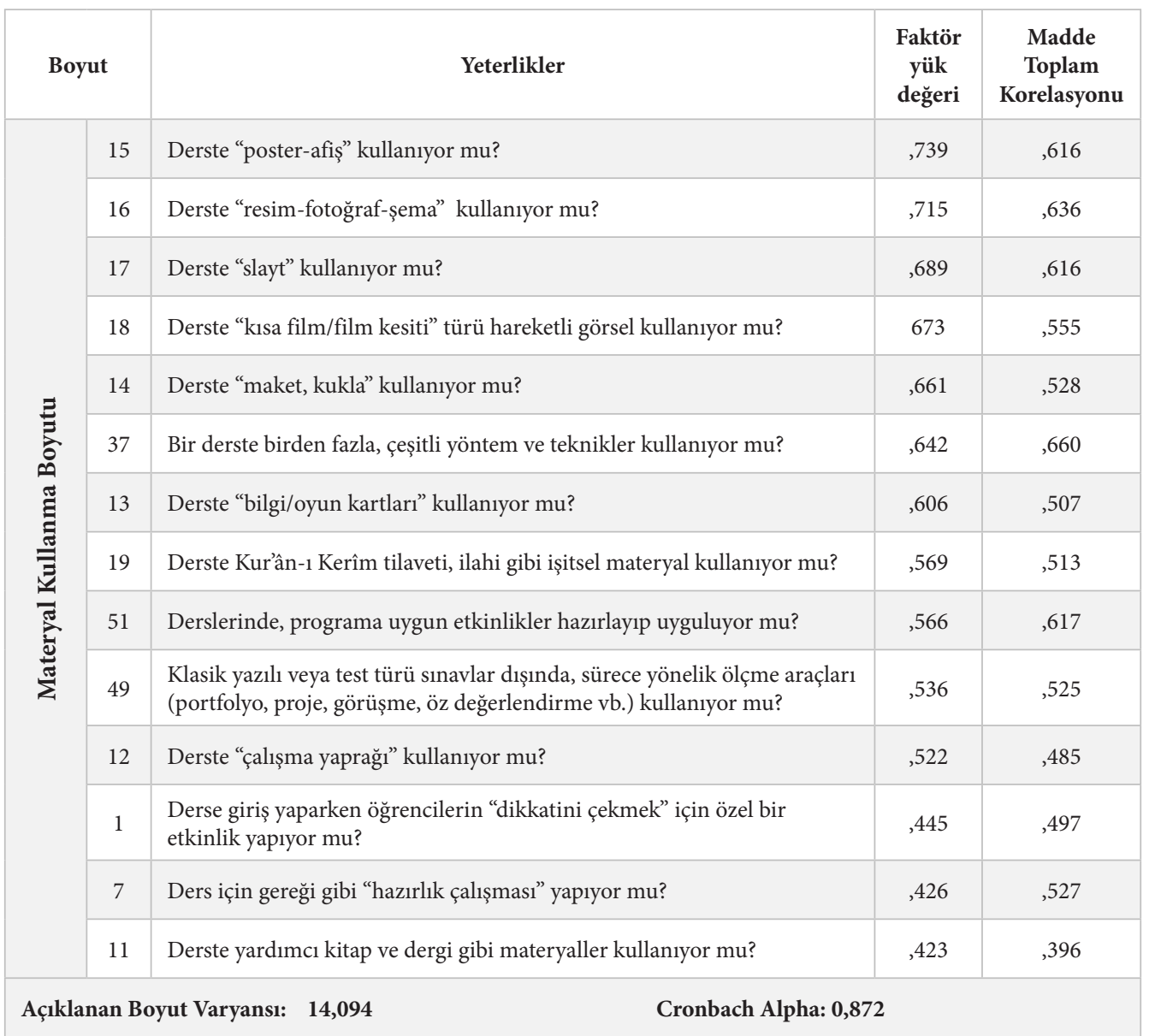


Tablo 9/C: Öğrenciyi Tanıma ve İletişim Boyutu Geçerlik ve Güvenirlik Analizi Sonuçları

\begin{tabular}{|c|c|c|c|c|}
\hline \multicolumn{2}{|c|}{ Boyut } & Yeterlikler & $\begin{array}{c}\text { Faktör } \\
\text { yük }\end{array}$ & $\begin{array}{l}\text { Madde } \\
\text { Toplam }\end{array}$ \\
\hline \multirow{8}{*}{ 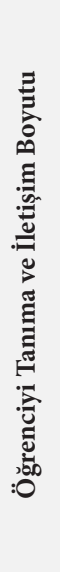 } & 47 & Öğrencilerine yeterince değer verip sevgi-saygı gösteriyor mu? & ,712 & ,749 \\
\hline & 43 & Öğrencileri tanımak, ilgi ve ihtiyaçlarını belirlemek için çaba gösteriyor mu? & 660 & ,701 \\
\hline & 52 & Öğretmenlik mesleğini severek yapıyor mu? & ,657 & ,675 \\
\hline & 48 & $\begin{array}{l}\text { Bir öğretmen olarak öğrencilerini (gelişim özellikleri, demografik } \\
\text { ve psikolojik özellikleri, size ve dersinize karşı tutumları açısından) } \\
\text { yeterince tanıyor mu? }\end{array}$ & ,626 & 694 \\
\hline & 44 & Hatalı olduğu durumlarda öğrencilerden özür diliyor mu? & ,603 &, 512 \\
\hline & 38 & Öğrencilere isimleriyle hitap etmek için özel çaba gösteriyor mu? &, 593 & 484 \\
\hline & 45 & Öğrenciler arasında adil davranıyor mu? &, 539 &, 567 \\
\hline & 24 & Öğrenciler için ders dışı etkinlikler düzenliyor mu? & ,486 & ,406 \\
\hline Açık & & ut Varyansı: 11,408 & & \\
\hline
\end{tabular}

Araştırmada faktör yüklerinin 0,45'in üzerinde olması ölçekte kullanılan maddelerin birbirleri ile yüksek düzeyde ilişki veren maddelerden oluştuğunu ve yapı geçerliğini sağlayacak niteliğe sahip bir ölçek özelliği taşıdığını göstermektedir. Aynı şekilde ölçekte yer alan soruların katılımcıları ne derece ayırt ettiğini göstermek amacıyla yapılan madde analizinde madde toplam korelasyonlarının da 0,39-0,74 arasında çıkması ölçekte yer alan ifadelerin ayırt edici olduğunu göstermektedir.

Testin güvenirlik analizinde cronbach alpha güvenirlik katsayıları birinci faktör için 0,93; ikinci faktör için 0,87; üçüncü faktör için ise 0,84 olarak bulunmuştur ki bu da ölçeği oluşturan maddeler arasında yüksek düzeyde bir iç tutarlılığın olduğu ve birbiri ile ilişkili maddelerden oluştuğu manasına gelmektedir. Sosyal bilimlerde bir test için güvenirlik katsayısının 0,70 ve daha yüksek olması, test puanlarının güvenirliği için genel olarak yeterli kabul edilmektedir. ${ }^{11}$ Bu doğrultuda, araştırmada kullanılan ölçeğin üç boyutu için de güvenilir olduğu söylenebilir.

\section{Bulgular ve Yorumlar}

Eğitimde başarının sağlanması için, öğretim programı, öğretim materyali, öğretim ortamı ve öğretmenin bir bütün halinde hedefler doğrultusunda bir araya gelmesi gerekmektedir. ${ }^{12} \mathrm{Bu}$ dört ana unsurdan birisi olan öğretmen, bu unsurlar arasındaki en önemli yere

11 Büyüköztürk, Sosyal Bilimler İçin Veri Analizi El Kitabı, s. 183; Durmuş - v.dğr., Sosyal Bilimlerde SPSS’le Veri Analizi, s. 89.

12 Nevzat Aşıkoğlu, "Din Öğretiminde Öğretmenin Rolü ve Din Dersi Öğretmeninin Yeterlilikleri (Türkiye Örneği)",

C.Ü. İlahiyat Fakültesi Dergisi, XV/1, 2001, s. 6-7. 
sahiptir. Zira diğer üç unsur ancak mesleğini seven, öğretmen yeterliklerine sahip, maharetli bir öğretmenin elinde anlam kazanacaktır. Özellikle konu din olduğunda öğretmenden beklentiler daha önemli bir hal almaktadır.

\section{1. Öğrenme - Öğretme Boyutu ile İlgili Bulgular}

Araştırmaya katılan öğretmen adaylarının gözlemledikleri öğretmenlerin "öğrenme-öğretme boyutu” ile ilgili öngörülen yeterliklere sahip olma düzeylerini gösteren ortalama değerlerin büyükten küçüğe doğru sıralanmış hali aşağıdaki tablodaki gibidir:

Tablo 10: Öğrenme-Öğretme Süreci Boyutundaki Yeterliklere Sahip Olma Düzeyleri

\begin{tabular}{|c|c|c|c|}
\hline \multicolumn{2}{|c|}{ Öğrenme-Öğretme Süreci Boyutu ile İlgili Yeterlikler } & \multirow{2}{*}{$\begin{array}{c}\bar{X} \\
3,02\end{array}$} & \multirow{2}{*}{$\begin{array}{c}\text { Tutum } \\
\text { Düzeyi } \\
\text { Orta }\end{array}$} \\
\hline 2 & $\begin{array}{l}\text { Derse giriş yaparken öğrencilerin derse motive olmasını sağlayacak güdüleme } \\
\text { ve hedeften haberdar etme etkinliklerini yapıyor mu? }\end{array}$ & & \\
\hline 36 & $\begin{array}{l}\text { Ders işlerken, öğrencileri düşünmeye sevk eden, anlamlı ve derinliği olan } \\
\text { sorular soruyor mu? }\end{array}$ & 2,75 & " \\
\hline 8 & Dersin sonunda öğrenilenleri kontrol edip, gerekli düzeltmeleri yapıyor mu? & 2,70 & $”$ \\
\hline 6 & Ders işlerken ara özet yapıyor mu? & 2,59 & $\mathrm{Az}$ \\
\hline 34 & $\begin{array}{l}\text { Derse girdiğinde fiziki veya psikolojik açıdan sınıf atmosferine dikkat edip, } \\
\text { duruma göre gerekli girişimlerde bulunuyor mu? }\end{array}$ & 2,57 & $"$ \\
\hline 31 & Öğrencilerde dinle ilgili araştırma, soru sorma isteği uyandırıyor mu? & 2,55 & $”$ \\
\hline 9 & Dersin sonunda bir özet ve değerlendirme yapıyor mu? & 2,54 & $"$ \\
\hline 29 & $\begin{array}{l}\text { Sınıf içinde tüm öğrencilerin sürece katılımını sağlayacak etkili bir iletişim } \\
\text { ortamı oluşturabiliyor mu? }\end{array}$ & 2,52 & $"$ \\
\hline 30 & İletişimde beden dilini etkili kullanıyor mu? & 2,40 & $"$ \\
\hline 35 & Ders işlerken öğrencilerin konuyla ilgili ön bilgilerini dikkate alıyor mu? & 2,40 & $"$ \\
\hline 5 & Ders konularını günlük hayatla ilişkilendiriyor mu? & 2,15 & $"$ \\
\hline 39 & Sınıf içi etkileşimde disiplin ve kontrolü sağlayabiliyor mu? & 2,13 & $”$ \\
\hline 32 & Derste sesini etkili kullanabiliyor mu? & 2,12 & $"$ \\
\hline 26 & Derslere giriş-çıkışlarda ve ders süresince zamanı etkin kullanıyor mu? & 2,08 & $”$ \\
\hline 4 & Ders işlerken konuyu önceki ve sonraki konularla ilişkilendiriyor mu? & 2,07 & $"$ \\
\hline 27 & Öğrencilerin sorularına uygun ve yeterli cevaplar veriyor mu? & 1,94 & $”$ \\
\hline 25 & İletişimde sözel dili anlaşılır ve etkili biçimde kullanıyor mu? & 1,91 & ” \\
\hline 22 & Dinî kavramları öğrencilerin seviyesine göre açık ve anlaşlır biçimde sunuyor mu? & 1,80 & $"$ \\
\hline 28 & Öğrencilerle göz iletişimi kuruyor mu? & 1,67 & Hiç \\
\hline & Boyut Ortalaması & 2,31 & $\mathrm{Az}$ \\
\hline
\end{tabular}


Tablo 10'da görüldüğü gibi araştırmada öğretmenlerin, "öğrenme-öğretme" boyutundaki yeterliklerden 3'üne "orta", 15'ine "az", 1'ine ise "hiç" derecelerinde sahip oldukları gözlemlenmiştir.

Yapılan gözlem sonuçlarına göre, öğretmenlerin bu alandaki ortalama puanları 1,67 ile 3,02 arasında değişmektedir. Bu alanda öğretmenlerin sadece üç alanda orta düzeyde yeterliğe sahip oldukları, diğer yeterlik alanlarına ise az düzeyde sahip oldukları gözlemlenmiştir. Ortaya çıkan tabloya göre, araştırmaya konu olan öğretmenlerin bu boyuttaki yeterlik ortalamaları "az" düzeydedir. Bu alanda daha önce yapılmış ve öğretmenlerin kendileri tarafından cevaplanmış anket sorularında ise tabloda yer alan yeterlik alanları ile ilgili öğretmenlerin ortalamalarının genel olarak "oldukça" düzeyinde olduğu görülmektedir. ${ }^{13}$ Acuner - Erbaş tarafından yapılan bir araştırmada ise; öğrenme-öğretme sürecine ait yeterlik alanı, DKAB öğretmenleri kendilerini geliştirmeyi düşündükleri ikinci yeterlik alanı olarak ifade edilmiştir. Bu çalışmada DKAB öğretmenleri sahip olmaları gereken ilk yeterlik alanını "ilahiyat alan bilgisi” olarak görmektedirler. Diğer branş öğretmenlerinin görüşlerine de başvurularak yapılan bu çalışmada, diğer branş öğretmenleri ise bir DKAB öğretmeninde görmek istedikleri yeterlik alanlarından birinci ve ikinci sıraya kişisel ve mesleki gelişimi koyarken, üçüncü sıraya ise öğrenme-öğretme yeterliğini koymuşlardır. ${ }^{14}$

Daha önceki çalışma sonuçları ile bu araştırma sonuçları arasında var olan farklılıklar, öğretmenlerin kendi yeterlik düzeylerinin ya yeterince farkında olmadıklarını ya da sahip oldukları yeterlikleri sınıf ortamına taşıyamadıklarını göstermektedir. Örneğin öğretmenlerin kendi cevapları doğrultusunda yapılan bir çalışmada öğretmenler "öğrencilerle göz iletişimi kurma" konusunda kendilerini "tam", ${ }^{15}$ başka çalışmalarda ise "oldukça" düzeyinde yeterliğe sahip görürken, ${ }^{16}$ bu çalışmada bu yeterlik düzeyinin "hiç" düzeyinde olduğu ortaya çıkmıştır.

Araştırmaya konu olan din ile ilgili derslere giren öğretmenlerin "öğrenme-öğretme" boyutundaki yeterlik düzeylerinin "cinsiyet", "yaş", "çalıştıkları okul türü" ve "dersi işleme yöntemi”ne göre aralarında istatistiksel açıdan bir farklılaşma olup olmadı̆̆g ile ilgili analiz sonuçları ise aşağıda incelenmiştir.

13 Koç, “Din Kültürü ve Ahlak Bilgisi Öğretmenlerinin Öğretme-Öğrenme Sürecine İlişkin Yeterlikleri”, s. 542-544; Süleyman Akyürek, "İmam Hatip Lisesi Meslek Dersi ile Din Kültürü ve Ahlak Bilgisi Öğretmenlerinin EğitimÖğretim Yeterliklerine İlişkin Algılar”, Değerler Eğitimi Dergisi, 10/23, Haziran 2012, s. 20-22.

14 Hacı Yusuf Acuner - Ahmet Akif Erbaş, "Din Kültürü ve Ahlak Bilgisi ve Diğer Branş Öğretmenlerine Göre Din Kültürü ve Ahlak Bilgisi Öğretmenlerinin Yeterlikleri”, Din Bilimleri Akademik Araştırma Dergisi, 16/1, 2016, s. 158160.

15 Davut Işıkdoğan, İlköğretim Din Kültürü Ve Ahlak Bilgisi Öğretmenliği Bölümü Mezunu Öğretmenlerin Yeterlikleri (doktora, 2006), Ankara Üniversitesi Sosyal Bilimler Enstitüsü, s. 116.

16 Eyüp Şimşek, İlköğretim Din Kültürü ve Ahlak Bilgisi Öğretmenlerinin Yeterlikleri (Erzurum Örneği) (doktora, 2006), Atatürk Üniversitesi Sosyal Bilimler Enstitüsü, s. 118; Yunus Emre Kars, Din Kültürü ve Ahlak Bilgisi Öğretmenlerinin Kendi Algılarına Dayalı Sını Yönetimi Yeterlikleri (Konak İlçesi Örneği) (yüksek lisans, 2007), Dokuz Eylül Üniversitesi Sosyal Bilimler Enstitüsü, s. 73. 
Tablo 11: “Öğrenme-Öğretme” Boyutu "Cinsiyet”e Göre Bağımsız Örneklem T-Testi Sonuçları

\begin{tabular}{|l|c|c|c|c|c|c|c|}
\hline $\begin{array}{l}\text { Öğrenme- } \\
\text { Öğretme } \\
\text { Boyut Toplamı }\end{array}$ & Cinsiyet & $\mathbf{N}$ & $\overline{\mathbf{X}}$ & $\mathbf{S}$ & $\mathbf{s d}$ & $\mathbf{t}$ & $\mathbf{p}$ \\
\cline { 2 - 8 } Ortalaması & Kadın & 211 & 43,43 & 12,76 & 329 & 1,02 & $\mathbf{0 , 3 0}$ \\
\cline { 2 - 7 } & Erkek & 120 & 44,99 & 14,06 & & & \\
\hline
\end{tabular}

Tabloya göre, öğrenme-öğretme yeterliği boyutunda öğretmenlerin cinsiyetlerine göre anlamlı bir farklılık olmadığı sonucu ortaya çıkmaktadır. ( $\mathrm{p}>, 05)$ Bu bulgu bize öğretmenlerin cinsiyetlerinin, bu boyutta yer alan yeterlikler konusunda etkili bir faktör olmadı̆̆ını göstermektedir. Konu ile ilgili yapılan bazı çalışmalarda, cinsiyet öğrenme-öğretme sürecinde etkili bir faktör olarak çıkmazken; ${ }^{17}$ bazılarında ise kadınlar lehine bir farklılık çıkmaktadır. ${ }^{18}$

Tablo 12: Öğrenme-Öğretme Boyutu Yaş Gruplarının Betimsel İstatistikleri

\begin{tabular}{|l|c|c|c|}
\hline Yaş Grubu & N & $\overline{\mathbf{X}}$ & $\mathbf{S S}$ \\
\hline $\mathbf{2 0 - 2 9}$ & 46 & 42,50 & 14,37 \\
\hline $\mathbf{3 0 - 3 9}$ & 179 & 42,60 & 11,97 \\
\hline $\mathbf{4 0 - 4 9}$ & 76 & 45,57 & 14,33 \\
\hline $\mathbf{5 0 - 5 9}$ & 30 & 50,60 & 14,10 \\
\hline Toplam & 331 & 44,00 & 13,25 \\
\hline
\end{tabular}

Tablo 13: “Öğrenme-Öğretme” Boyutunda "Yaş Gruplarına” Göre Varyansların Homojenliği Testi (Levene)

\begin{tabular}{|c|c|c|c|}
\hline \multirow{2}{*}{ Levene Testi } & İstatistik & Serbestlik Derecesi & p \\
\cline { 2 - 4 } & 2,45 & 3 & 0,06 \\
\hline
\end{tabular}

Yapılan analiz sonuçlarından varyansların homojen olduğu anlaşıldığından analiz sonuçları anova testi yapılmasının uygun olduğunu göstermektedir.

Tablo 14: Öğrenme-Öğretme Boyutu "Yaş Gruplarına” Göre Anova Sonuçları

\begin{tabular}{|l|c|c|c|c|c|c|}
\hline $\begin{array}{l}\text { Varyansın } \\
\text { Kaynağı }\end{array}$ & $\begin{array}{c}\text { Kareler } \\
\text { Toplamı }\end{array}$ & Sd & $\begin{array}{c}\text { Kareler } \\
\text { Ortalaması }\end{array}$ & F & p & Anlamlı Fark \\
\hline Gruplar arası & 1946,148 & 3 & 648,716 & 3,78 & 0,011 & (50-59)-(20-29) \\
\cline { 1 - 5 } Gruplar içi & 55999,852 & 327 & 171,253 & & & \\
\cline { 1 - 3 } Toplam & 57946,000 & 330 & & & & \\
\hline
\end{tabular}

17 Işıkdoğan, İlköğretim Din Kültürü ve Ahlak Bilgisi Öğretmenliği Bölümü Mezunu Öğretmenlerin Yeterlikleri, s. 117; Ahmet Koç, "İmam Hatip Lisesi Meslek Dersi Öğretmenlerinin Yeterlikleri Üzerine Bir Araştırma”, C.Ü. İlahiyat Fakültesi Dergisi, XIII/2, s. 162.

18 Koç, "Din Kültürü ve Ahlak Bilgisi Öğretmenlerinin Öğretme-Öğrenme Sürecine İlişkin Yeterlikleri”, s. 544-546; Mahmut Zengin, "Din Kültürü ve Ahlak Bilgisi Öğretmenlerinin Eğitim Öğretim Yeterlik Algıları”, Sakarya İlahiyat Fakültesi Dergisi, XV/27, (2013/1), s. 17. 
Yukarıda yer alan analiz sonuçları, öğretme yeterliği boyutunda öğretmenlerin yaş gruplarına göre farklılaştığını göstermektedir $(\mathrm{F}(3,327)=3,78, \mathrm{p}<0,05$. $)$. Farklılaşmanın hangi yaş grupları arasında olduğunu bulmak amacıyla yapılan LSD testinin sonuçlarına göre, 5059 yaş grubunda $(\overline{\mathrm{x}}=50,60)$ bulunan öğretmenler 20-29 $(\overline{\mathrm{x}}=42,50)$ ve 30-39 $(\overline{\mathrm{x}}=42,60)$ yaş grubunda bulunan öğretmenlere kıyasla daha yüksek puan almışlardır. Başka bir deyişle öğrenme-öğretme boyutu yeterliği konusunda yaş faktörü olumlu bir etki göstermektedir.

Tablo 15: Öğrenme-Öğretme Boyutu Yeterlik Ortalama Puanlarının Öğretmenlerin Görev Yaptığı Okul Türlerine Göre Betimsel İstatistikleri

\begin{tabular}{|l|c|c|c|}
\hline Okul Türü & $\mathbf{N}$ & $\overline{\mathbf{X}}$ & SS \\
\hline İlkokul & 14 & 36,92 & 7,77 \\
\hline Orta Okul & 110 & 42,44 & 13,07 \\
\hline İmam Hatip Ortaokulu & 54 & 47,16 & 11,49 \\
\hline Anadolu İHL & 70 & 45,14 & 14,85 \\
\hline Meslek Lisesi & 55 & 46,18 & 15,04 \\
\hline Anadolu Lisesi & 18 & 40,72 & 7,44 \\
\hline Spor Lisesi & 10 & 39,80 & 9,91 \\
\hline Toplam / Ortalama & $\mathbf{3 3 1}$ & $\mathbf{4 4 , 0 0}$ & $\mathbf{1 3 , 2 5}$ \\
\hline
\end{tabular}

Tablo 16: "Öğrenme-Öğretme” Boyutunda “Okul Türlerine” Göre Varyansların Homojenliği Testi (Levene)

\begin{tabular}{|c|c|c|c|}
\hline \multirow{2}{*}{ Levene Testi } & İstatistik & Serbestlik Derecesi & $\mathbf{p}$ \\
\cline { 2 - 4 } & 2,37 & 6 & 0,02 \\
\hline
\end{tabular}

Yapılan analizde grup varyansların homojen olmadığ gibi durumlarda (F testi yapılamayacağından) alternatif bir yol olarak Welch veya BrownForsythe testlerinin yapılabileceği, bu iki test arasında ise Welch testinin daha güçlü olup daha sık kullanıldığı belirtilmiştir. ${ }^{19}$

Tablo 17: "Öğrenme-Öğretme" Boyutunda "Okul Türlerine" Göre Welch Testi

\begin{tabular}{|c|c|c|c|}
\hline \multirow{2}{*}{ Welch } & İstatistik & Serbestlik Derecesi & $\mathbf{p}$ \\
\cline { 2 - 4 } & 3,55 & 6 & 0,004 \\
\hline
\end{tabular}


Tablo 18: Öğrenme-Öğretme Boyutu “Okul Türlerine” Göre Dunnett C Testi

\begin{tabular}{|c|c|c|c|}
\hline \multirow{2}{*}{ Dunnett C } & Okul Türüi & Ortalamaların Farki & $\mathbf{s x}$ \\
\cline { 2 - 4 } & İHO-İlkokul & $10,23810^{\star}$ & 2,60 \\
\hline
\end{tabular}

Yapılan bu testler sonucunda, farklı okul türlerinde çalışan öğretmenlerin arasında öğretme yeterliği boyutundaki ortalamaların farklılaşması anlamlı bulunmuştur ( $\mathrm{p}<0.01)$. Hangi okul türlerinde çalışan öğretmenler arasında fark olduğunun tespiti için ise varyansların homojen olmadığı durumlarda başvurulan testlerden bir tanesi olan Dunnett $\mathrm{C}$ testinden faydalanılmıştır. Bu testin sonuçlarına göre İmam Hatip Ortaokulunda çalışan öğretmenler $(\overline{\mathrm{x}}=47,16)$ ile ilköğretimde çalışan öğretmenler $(\overline{\mathrm{x}}=36,92)$ arasında öğretme yeterliği açısından İHO’da çalışan öğretmenler lehine anlamlı bir fark olduğu görülmektedir.

Din dersi öğretmenlerinin aynı öğretim programından mezun olmalarına rağmen, çalıştıkları okul türüne göre öğretmen yeterliklerinin farklılaşması, özellikle ilköğretim seviyesinde ortalama yeterlik puanlarının düşük çıkması, ilahiyat programında ilköğretim seviyesine yönelik olarak din öğretiminin nasıl yapılacağı ile ilgili farklı çalışmalara ihtiyaç duyulduğunu ortaya koymaktadır.

Tablo 19: “Öğrenme-Öğretme” Boyutu “Ders İşleme Yöntemi”ne Göre Bağımsız Örneklem T-Testi Sonuçları

\begin{tabular}{|l|l|c|c|c|c|c|c|}
\hline & Öğretim Yöntemi & N & $\overline{\mathbf{X}}$ & $\mathbf{S}$ & sd & $\mathbf{t}$ & $\mathbf{p}$ \\
\hline $\begin{array}{l}\text { Öğrenme-Öğretme } \\
\text { Boyutu Toplamı } \\
\text { Ortalaması }\end{array}$ & Öğretmen Merkezli & 255 & 46,30 & 12,99 & & & \\
\cline { 2 - 7 } & Öğrenci Merkezli & 76 & 36,27 & 11,06 & 329 & 6,098 & 0,00 \\
\hline
\end{tabular}

Öğretim yöntemleri genel olarak öğretmen ve öğrenciyi merkeze almasına göre öğretmen ve öğrenci merkezli olmak üzere ikiye ayrılmaktadır. Yapılan analize göre, öğretmenin öğretmen ve öğrenci merkezli yöntemler kullanması öğrenme-öğretme yeterliği boyutunda anlamlı bir farklılık göstermektedir $(\mathrm{t}(329)=6,098 ; \mathrm{p}<0.05)$. Öğrenme-öğretme boyutunda gözlemlenen öğretmenlerden, derslerini daha çok öğretmen merkezli yöntemlerle işleyenlerin $(\overline{\mathrm{x}}=46,30)$ öğrenci merkezli yöntemlerle işleyenlere $(\overline{\mathrm{x}}=36,27)$ göre daha yüksek puan aldıkları görülmektedir.

Öğretmen merkezli yöntemler daha eski ve sık kullanılan yöntemler olduğundan uygulama biçimleri oturmuş ve neredeyse standardize olmuştur. Oysa öğrenci merkezli yöntemler daha yeni yeni kullanılmaya başlanılmış olup uygulama noktasında belirsizlikleri bünyesinde barındırmaktadır. Bu yöntemlerin nasıl anlaşılıp kullanılması gerektiği ile ilgili öğretmenler camiasında ortak bir görüşten söz etmek mümkün değildir. Aynı şekilde, öğretmen merkezli yöntemleri kullanan öğretmen sayısının da öğrenci merkezli yöntemleri kullanan öğretmenlere kıyasla daha fazla olduğu bilinen bir gerçektir. 


\section{2. Materyal Kullanma Boyutu ile İlgili Bulgular}

Eğitim ve öğretim sürecinde ne kadar çok duyu organına hitap edilirse, kalıcı öğrenme de o oranda artmaktadır. Eğitim-öğretim sürecinde materyal kullanımı, dersin monotonluktan çıkması ve öğretmenin farklı duyulara hitap etmesini sağlayan önemli bir faktördür. Araştırmaya katılan öğretmen adaylarının gözlemledikleri öğretmenlerin "materyal kullanma” boyutu ile ilgili öngörülen yeterliklere sahip olma düzeylerini gösteren ortalama değerlerin, büyükten küçüğe doğru sıralanmış hali aşağıdaki tablodaki gibidir:

Tablo 20: "Materyal Kullanma” Boyutundaki Yeterliklere Sahip Olma Düzeyleri

\begin{tabular}{|c|c|c|c|}
\hline \multicolumn{2}{|c|}{ Materyal Kullanma Boyutu ile İlgili Yeterlikler } & \multirow{2}{*}{$\begin{array}{c}\bar{X} \\
4,74\end{array}$} & \multirow{2}{*}{$\begin{array}{c}\text { Tutum } \\
\text { Düzeyi } \\
\text { Tam }\end{array}$} \\
\hline 14 & Derste "maket, kukla" kullanıyor mu? & & \\
\hline 13 & Derste "bilgi/oyun kartları" kullanıyor mu? & 4,53 & ” \\
\hline 15 & Derste "poster-afiş" kullanıyor mu? & 4,52 & $"$ \\
\hline 12 & Derste "çalışma yaprağı" kullanıyor mu? & 3,80 & Oldukça \\
\hline 18 & Derste "kısa film/film kesiti" türü hareketli görsel kullanıyor mu? & 3,77 & ” \\
\hline 16 & Derste "resim-fotoğraf-şema" kullanıyor mu? & 3,74 & $"$ \\
\hline 49 & $\begin{array}{l}\text { Klasik yazılı veya test türü sınavlar dışında, sürece yönelik ölçme araçları (portfolyo, } \\
\text { proje, görüşme, öz değerlendirme vb.) kullanıyor mu? }\end{array}$ & 3,59 & ” \\
\hline 37 & Bir derste birden fazla, çeşitli yöntem ve teknikler kullanıyor mu? & 3,56 & ” \\
\hline 19 & Derste Kur'ân-ı Kerîm tilaveti, ilahi gibi işitsel materyal kullanıyor mu? & 3,49 & $"$ \\
\hline 1 & Derse giriş yaparken öğrencilerin "dikkatini çekmek" için özel bir etkinlik yapıyor mu? & 3,48 & ” \\
\hline 17 & Derste "slayt" kullanıyor mu? & 3,41 & ” \\
\hline 11 & Derste yardımcı kitap ve dergi gibi materyaller kullanıyor mu? & 3,35 & Orta \\
\hline 51 & Derslerinde, programa uygun etkinlikler hazırlayıp uyguluyor mu? & 3,16 & $"$ \\
\hline 7 & Ders için gereği gibi “hazırlık çalışması" yapıyor mu? & 2,89 & $"$ \\
\hline & Boyut Ortalaması & 3,71 & Oldukça \\
\hline
\end{tabular}

Yukarıdaki tablodan görüleceği üzere, öğretmenlerin “materyal kullanma” boyutundaki yeterliklerden 3'üne "tam”, 8'ine “oldukça”, 3'üne ise "orta” düzeyde sahip oldukları görülmektedir. Öğretmenlerin "materyal kullanma” boyutundaki yeterliklere ilişkin ortalama puanları ise 2,89-4,74 arasında değişmektedir. Bu ortalama puanlar aynı zamanda, çalışmaya konu olan üç boyut içerisindeki en yüksek ortalama puanlardır. 
Bu puanlar daha önce yapılan çalışmalar ile kıyaslandığında, daha önceki çalışmalara göre yüksek çıkmaktadır. 2007-2008 yılında yapılan çalışmada bu alanda öğretmen yeterliklerinin genel olarak "orta" düzeyde çıktığı, öğretmenlerin materyal hazırlama ve bulma konusunda ise problem yaşadıkları ifade edilmiştir. ${ }^{20} \mathrm{Hem}$ gelişen teknolojik imkânlarla birlikte özellikle dijital olarak ders materyallerine daha kolay ulaşılması, hem de hemen hemen artık her sınıfta akıllı tahta olmasının, öğretmenlerin bu boyuttaki yeterlik puanlarının yüksek çıkmasına imkân verdiği söylenebilir. Aynı şekilde öğretmen yetiştirme programlarında iki dönem olarak okutulan bilgisayar dersi ile öğretim teknolojileri ve materyal tasarım derslerinin de bu boyuttaki puanların yüksek çıkmasına katkıda bulunduğu ifade edilebilir.

Öğretmenlerin "materyal kullanma" boyutundaki yeterlik düzeylerinin "cinsiyet", "yaş", "çalıştıkları okul türü" ve "ders işleme yöntemi”ne göre aralarında istatistiksel açıdan bir farklılaşma olup olmadığı ile ilgili analiz sonuçları ise aşağıda incelenmiştir.

Tablo 21: "Materyal Kullanma” Boyutu "Cinsiyet"e Göre Bağımsız Örneklem T-Testi Sonuçları

\begin{tabular}{|c|c|c|c|c|c|c|c|}
\hline \multirow{3}{*}{$\begin{array}{l}\text { Materyal } \\
\text { Kullanma } \\
\text { Boyut Toplamı } \\
\text { Ortalaması }\end{array}$} & Cinsiyet & $\mathbf{N}$ & $\overline{\mathbf{X}}$ & $S$ & sd & $\mathbf{t}$ & $\mathbf{p}$ \\
\hline & Kadın & 211 & 50,68 & 10,13 & \multirow{2}{*}{329} & \multirow{2}{*}{3,44} & \multirow{2}{*}{0,01} \\
\hline & Erkek & 120 & 54,60 & 9,57 & & & \\
\hline
\end{tabular}

Gözlenen öğretmenlerin "materyal kullanma” boyutu toplam puan ortalamalarının "cinsiyet"e göre farklılık gösterip göstermediği de t-testi ile belirlenmeye çalışılmış ve analiz sonuçları Tablo 20'de verilmiştir.

Bu bulgulara göre araştırmaya katılan erkek öğretmenlerin materyal kullanma boyutundaki toplam puan ortalamaları $(\bar{X}=54,60)$ kadın öğretmenlerin toplam puan ortalamalarından $(\bar{X}=50,68)$ yüksektir ve bu farklılaşma istatistiksel olarak da anlamlıdır. $(\mathrm{t}(329)=3,44$; $\mathrm{p}<0,05)$.

Görüldüğü gibi materyal kullanma boyutunda cinsiyet faktörü önemli çıkmıştır. Bu sonuca göre, erkek öğretmenlerin derslerinde daha fazla materyal kullandıkları göze çarpmaktadır. Bu durum, daha önce öğretmen yeterlikleri ile ilgili yapılan çalışma sonuçlarından farkllılk arz etmektedir. Ahmet Koç tarafından daha önce DKAB öğretmenlerinin yeterlikleri üzerine yapılan çalışmada, kadın öğretmenlerin materyal kullanma boyutundaki yeterlik algılarının erkek öğretmenlere göre daha yüksek olduğu sonucu çımıştı. ${ }^{21}$ İki çalışma arasındaki bu farklılık, kadın öğretmenlerin materyal kullanma konusunda kendilerini yeterli görmelerine karşın, sınıfta yapılan gözlemlerde materyal kullanımı konusunda aynı yeterliği göstermediklerini ortaya koymaktadır.

20 Koç, "Din Kültürü ve Ahlak Bilgisi Öğretmenlerinin Öğretme-Öğrenme Sürecine İlişkin Yeterlikleri”, s. 536-538.

21 Koç, "Din Kültürü ve Ahlak Bilgisi Öğretmenlerinin Öğretme-Öğrenme Sürecine İlişkin Yeterlikleri”, 536-539. 
Tablo 22: Materyal Kullanma Boyutu Yeterlik Ortalama Puanlarının Yaş Gruplarına Göre Betimsel İstatistikleri

\begin{tabular}{|c|c|c|c|}
\hline Yaş Grubu & N & $\overline{\mathbf{X}}$ & SS \\
\hline $\mathbf{2 0 - 2 9}$ & 46 & 48,19 & 9,93 \\
\hline $\mathbf{3 0 - 3 9}$ & 179 & 51,13 & 10,12 \\
\hline $\mathbf{4 0 - 4 9}$ & 76 & 54,26 & 9,56 \\
\hline $\mathbf{5 0 - 5 9}$ & 30 & 58,40 & 7,59 \\
\hline Toplam & 331 & 52,10 & 10,09 \\
\hline
\end{tabular}

Tablo 23: "Materyal Kullanma” Boyutunda "Yaş Gruplarına” Göre Varyansların Homojenliği Testi (Levene)

\section{Levene Testi}

$$
1,03
$$

Serbestlik Derecesi

3 p

0,37

Yapılan analizde Levene testinin p değer 0,05'den büyük olduğundan $(0,37>0,05)$ varyansların homojen olduğu durumlarda yapılan anova testinin yorumlanmasına geçilebilir.

Tablo 24: "Materyal Kullanma” Boyutu "Yaş Gruplarına” Göre Anova Sonuçları

\begin{tabular}{|c|c|c|c|c|c|c|}
\hline $\begin{array}{c}\text { Varyansın } \\
\text { Kaynağı }\end{array}$ & $\begin{array}{c}\text { Kareler } \\
\text { Toplamı }\end{array}$ & Sd & $\begin{array}{c}\text { Kareler } \\
\text { Ortalaması }\end{array}$ & F & p & Anlamlı Fark \\
\hline Gruplar arası & 2412,615 & 3 & 804,205 & & & $\begin{array}{c}(40-49)-(20-29) \\
(40-49)-(30-39)\end{array}$ \\
\hline Gruplar içi & 31238,684 & 327 & 95,531 & 8,41 & 0,000 & $\begin{array}{r}(50-59)-(20-29) \\
(50-59)-(30-39)\end{array}$ \\
\hline Toplam & 33651,299 & 330 & & & & \\
\hline
\end{tabular}

Yukarıda yer alan analiz sonuçları, materyal kullanma boyutunda öğretmenlerin yaş gruplarına göre farklılaştığını göstermektedir. [ F $(3,327)=8,41 ; \mathrm{p}<0,05$.] Yapılan analizde, gözlemlenen öğretmenlerin yaşlarına göre materyal kullanma yeterliği konusunda anlamlı bir şekilde farklılaştıkları görülmektedir. Farklılaşmanın hangi yaş grupları arasında olduğunu bulmak amacıyla yapılan LSD testinin sonuçlarına göre, 50-59 yaş grubunda $(\overline{\mathrm{x}}=58,40)$ bulunan öğretmenlerin 20-29 $(\overline{\mathrm{x}}=48,19)$ ve 30-39 $(\overline{\mathrm{x}}=51,13)$ yaş grubunda bulunan öğretmenlere ve aynı şekilde 40-49 yaş grubunda $(\overline{\mathrm{x}}=54,26)$ bulunan öğretmenlerin 20-29 $(\overline{\mathrm{x}}=48,19)$ ve 30-39 $(\overline{\mathrm{x}}=51,13)$ yaş grubunda bulunan öğretmenlere nazaran daha yüksek puanlar aldıkları görülmektedir.

$\mathrm{Bu}$ araştırma sonuçlarına göre materyal kullanma becerisi boyutunda, öğretmenlerin yaşları ilerledikçe materyal kullanma yeterliği puanlarının da arttığı, dikkati çekmektedir. Genelde öğretmenlerin yaşları ve kıdemleri ilerledikçe materyal kullanma konusunda daha pasif davrandıkları düşüncesinin aksine, sınıf içi gözlemlere dayalı bu araştırma 
sonuçlarında öğretmenlerin yaşları ilerledikçe (40 yaş üstü) materyal kullanma konusunda daha aktif oldukları ortaya çıkmıştır. Bu durum öğretmenlerin yaş ve tecrübeleri arttıkça derslerde materyal kullanmanın faydalarını, daha fazla gördükleri sonucunu ortaya koymaktadır.

Benzer sonuçlara, 2017 yılında sınıf öğretmenleri ile ilgili yapılan bir çalışmada daha rastlanılmaktadır. Bu çalışmada, sınıf öğretmenlerinin teknoloji kullanımı ile mesleki kıdemleri arasındaki ilişkiye bakıldığında 16 yıl ve üzeri kıdeme sahip sınıf öğretmenlerinin teknoloji kullanımı konusunda daha yüksek puanlara sahip oldukları görülmektedir. ${ }^{22}$

Tablo 25: "Materyal Kullanma” Boyutunda "Görev Yapılan Okul Türlerine” Göre Varyansların Homojenliği Testi (Levene)

\begin{tabular}{|c|c|c|c|}
\hline \multirow{2}{*}{ Levene Testi } & İstatistik & Serbestlik Derecesi & $\mathbf{p}$ \\
\cline { 2 - 4 } & 5,59 & 6 & 0,00 \\
\hline
\end{tabular}

Yapılan analizde grup varyansların homojen olmadığı tespit edilmiştir. Bu durumlarda yapılan Welch testinin sonuçları ise aşağıdaki gibidir:

Tablo 26: "Materyal Kullanma” Boyutunda "Okul Türlerine” Göre Welch Testi Sonuçları

\begin{tabular}{|c|c|c|c|}
\hline \multirow{2}{*}{ Welch } & İstatistik & Serbestlik Derecesi & $\mathbf{p}$ \\
\cline { 2 - 4 } & 1,997 & 6 & $\mathbf{0 , 0 8}$ \\
\hline
\end{tabular}

Tabloda görüleceği üzere yapılan analiz sonucunda $p$ değerinin 0,05 'den büyük olması materyal kullanma boyutunda okul türlerine göre bir farklılık görülmediği sonucunu ortaya koymaktadır.

Tablo 27: "Materyal Kullanma” Boyutu “Ders İșleme Yöntemi”ne Göre Bağımsız Örneklem T-Testi Sonuçları

\begin{tabular}{|l|l|c|c|c|c|c|c|}
\hline $\begin{array}{l}\text { Materyal } \\
\text { Kullanma } \\
\text { Boyut Toplamı } \\
\text { Ortalaması }\end{array}$ & Öğgetim Yöntemi & N & $\overline{\mathbf{X}}$ & $\mathbf{S}$ & sd & $\mathbf{t}$ & $\mathbf{p}$ \\
\cline { 2 - 8 } & Öğretmen Merkezli Merkezli & 255 & 53,75 & 9,63 & & & \\
\hline
\end{tabular}

Yapılan analiz, öğretmenlerin dersi işleme yöntemindeki farklılaşmanın materyal kullanma boyutunda anlamlı bir farklılık gösterdiğini ortaya koymaktadır. [t(329) $=5,703$; $\mathrm{p}<0.05$.] Derslerini daha çok öğretmen merkezli işleyen öğretmenlerin $(\bar{x}=53,75)$ materyal kullanma boyutunda, öğrenci merkezli işleyenlere $(\overline{\mathrm{x}}=46,56)$ göre daha yüksek puan aldıkları görülmektedir.

22 Ahmet Melih Güneş - Bekir Buluç, "Sınıf Öğretmenlerinin Teknoloji Kullanımları ve Öz Yeterlilik İnançları Arasındaki İlişki”, TÜBAV Bilim Dergisi, 10/1, 2017, s. 104-105. 


\section{3. Öğrenciyi Tanıma ve İletişim Becerisi Boyutu ile İlgili Bulgular}

Eğitim-öğretim sürecinde öğrenciyi tanımak, öğrenciler ile etkili bir şekilde iletişim kurmak bu süreçte başarıyı önemli yönde etkileyen faktörlerden birisidir. Bu alanla ilgili öğretmenlerin sınıfta göstermiş oldukları yeterlik düzeyleri şu şekildedir:

Tablo 28: “Öğrenciyi Tanıma ve İletişim Becerisi” Boyutundaki Yeterliklere Sahip Olma Düzeyleri

\begin{tabular}{|c|c|c|c|}
\hline \multicolumn{2}{|r|}{ Öğrenciyi Tanıma ve İletişim Becerisi Boyutu ile İlgili Yeterlikler } & \multirow{2}{*}{$\begin{array}{c}\bar{X} \\
3,58\end{array}$} & \multirow{2}{*}{$\begin{array}{l}\text { Tutum } \\
\text { Düzeyi } \\
\text { Oldukça }\end{array}$} \\
\hline 24 & Öğrenciler için ders dışı etkinlikler düzenliyor mu? & & \\
\hline 44 & Hatalı olduğu durumlarda öğrencilerden özür diliyor mu? & 2,82 & Orta \\
\hline 43 & Öğrencileri tanımak, ilgi ve ihtiyaçlarını belirlemek için çaba gösteriyor mu? & 2,57 & $\mathrm{Az}$ \\
\hline 48 & $\begin{array}{l}\text { Bir öğretmen olarak öğrencilerini (gelişim özellikleri, demografik ve } \\
\text { psikolojik özellikleri, size ve dersinize karşı tutumları açısından) yeterince } \\
\text { tanıyor mu? }\end{array}$ & 2,35 & $”$ \\
\hline 38 & Öğrencilere isimleriyle hitap etmek için özel çaba gösteriyor mu? & 2,11 & ” \\
\hline 47 & Öğrencilerine yeterince değer verip sevgi-saygı gösteriyor mu? & 1,93 & ” \\
\hline 45 & Öğrenciler arasında adil davranıyor mu? & 1,86 & ” \\
\hline 52 & Öğretmenlik mesleğini severek yapıyor mu? & 1,85 & ” \\
\hline \multicolumn{2}{|r|}{ Boyut Ortalaması } & 2,38 & Az \\
\hline
\end{tabular}

Bu boyutla ilgili sınıfta gözlemlenen öğretmenlerin “öğrencileri tanıma ve iletişim” boyutundaki yeterliklerden 1'ine "oldukça”, 1'ine “orta”, 6'sına "az" düzeyde sahip oldukları görülmektedir. Öğretmenlerin “öğrenciyi tanıma ve iletişim becerisi” boyutundaki yeterliklere sahip olma düzeylerine ilişkin ortalama puanları ise 1,85-3,58 arasında değişmektedir.

Bu alanda yapılmış ilk çalışmalardan olan Doğan - Altaş’ın çalışmasında ilköğretimde ders veren DKAB dersi öğretmenlerinin, kendilerini en çok yeterli gördükleri alanlardan ikincisinin "etkili iletişim" olduğu ifade edilmektedir. ${ }^{23}$ Koç tarafından yapılan bir başka çalışmada ise, öğretmenlerin kendilerine bu alanda sorulan sorulara verdikleri cevapların, aritmetik ortalamalarının yüksek çıkmasına rağmen, öğretmenlerle yüz yüze görüşüldüğünde alınan cevapların bu yüksek ortalamayı desteklemediğini, DKAB dersine giren öğretmenlerin öğrencilerle iletişim kurarken zorlandıklarını ifade ettikleri belirtilmektedir. ${ }^{24}$ Veli görüşlerine dayanan bir çalışmada ise, velilerin DKAB öğretmeninden ilk beklentilerinin çocuklarını tanıması ve buna gayret etmesi olmuştur. ${ }^{25} \mathrm{Bu}$ çalışmadan çıkan sonuçlar da bunu destekler mahiyettedir.

23 Recai Doğan - Nurullah Altaş, “İlköğretim Din Kültürü ve Ahlak Bilgisi Öğretmenlerinin Yeterlik Düzeyini Belirleyen Faktörler (Ankara Örneği)”, Ankara Üniversitesi İlahiyat Fakültesi Dergisi, XLIV/2, 2003, s. 185. 
Burada "Öğretmenlik mesleğini severek yapıyor mu?" sorusuna verilen cevabın en düşük düzeyde çıkması oldukça üzücüdür. Daha önce yapılan farklı araştırmaların hepsi, hem DKAB dersi öğretmenlerinin, hem de imam hatip meslek dersi öğretmenlerinin mesleklerini severek yaptıklarını göstermektedir. ${ }^{26}$ Çalışmalar arasında bu denli bir farkın çıkması dikkat çekicidir. Bu sonuçları sadece bu çalışmanın sonuçları ile yorumlamak yeterli olmayacaktır. Bu farkın hem öğretmenlerin kendi görüşleri hem de d1şarıdan yapılan gözlemler sonucunda incelenmesi daha tutarlı yorum yapmaya olanak tanıyacağı aşikardır.

Bu boyutta dikkat çekici sonuçlardan birisi de "Öğrencilere isimleri ile hitap etme için özel çaba sarf ediyor mu?” sorusuna verilen cevaplarla ilgilidir. Bu soruya verilen cevaplara göre öğretmenlerin "az" düzeyde yeterli oldukları sonucu çıkmaktadır. Bu konuda daha önce yapılan çalışmalarda ise öğretmenlerin büyük kısmı öğrencilerine isimleri ile hitap etmek konusunda gayret ettiklerini belirtmişlerdir. ${ }^{27}$

Aynı şekilde bu boyutta “Öğrenciler arasında adil davranıyor mu?" sorusu en düşük puana sahip sonuçlardan birisidir. Sonuçlar, bu alanda öğretmenlerin 1,86 aritmetik ortalama ile "az" düzeyde yeterliğe sahip olduğunu göstermektedir. Sınıf içinde belki de adalet kavramını öğrencilerine en çok öğretmesi/benimsetmesi gereken öğretmenlerin bu alanda "az" düzeyde yeterlik göstermeleri üzücüdür. Hiçbir öğretmenin öğrencilerine, bilerek adaletsizlik yapmayacağını kabul ettiğimizde, bu sonucu öğretmenlerin sınıf içinde farkında olmadan, yapmış oldukları bazı davranışların aday öğretmenler tarafından adaletsizlik olarak algılandığı şeklinde yorumlamak mümkündür. Bununla birlikte, ilgili konuların çözümü ise öğretmenlerin bu konudaki durumlarının farkına varmaları ile olacaktır. Bu farkındalığın sağlanması ise öğretmenlerin meslekleri ile ilgili olumlu/olumsuz yönlerini görebilecekleri çeşitli değerlendirme araçları ile mümkün olabilir.

Öğretmenlerin "öğrenciyi tanıma ve iletişim” boyutundaki yeterlik düzeylerinin "cinsiyet", "yaş", "çalıştıkları okul türü" ve "dersi işleme yöntemi”ne göre istatistiksel açıdan bir farklılaşma olup olmadığı ile ilgili analiz sonuçları ise aşağıda incelenmiştir.

26 Koç, "İmam Hatip Lisesi Meslek Dersi Öğretmenlerinin Yeterlikleri Üzerine Bir Araştırma”, s. 142; Koç, "Din Kültürü ve Ahlak Bilgisi Öğretmenlerinin Yeterlikleri”, s. 117, 121; Işıkdoğan, İlköğretim Din Kültürü ve Ahlak Bilgisi Öğretmenliği Bölümü Mezunu Öğretmenlerin Yeterlikleri, s. 130; Şimşek, İlköğretim Din Kültürü ve Ahlak Bilgisi Öğretmenlerinin Yeterlikleri (Erzurum Örneği), s. 89; Işıl Yazıcı, İlköğretim Din Kültürü ve Ahlak Bilgisi Öğretmenlerinin Yeterlikleri (İstanbul İli Örneği Üzerinde Bir Alan Araşttrmasl) (yüksek lisans tezi, 2004) Ankara Üniversitesi Sosyal Bilimler Enstitüsü, s. 82; Akyürek, "İmam Hatip Lisesi Meslek Dersi ile Din Kültürü ve Ahlak Bilgisi Öğretmenlerinin Eğitim-Öğretim Yeterliklerine İlişkin Algılar", s. 27-28; Zengin, "Din Kültürü ve Ahlak Bilgisi Öğretmenlerinin Eğitim Öğretim Yeterlik Algıları”, s. 13.

27 Recep Uçar, İlköğretim Okulu II. Kademedeki Din Kültürü ve Ahlak Bilgisi Öğretmenlerinin Sinıf Yönetimi Yeterlikleri (Kayseri İl Merkezi Örneği) (doktora tezi, 2004), Erciyes Üniversitesi Sosyal Bilimler Enstitüsü, s. 81, 195; Hatice Fakioğlu Bağcl, İlköğretim Din Kültürü ve Ahlak Bilgisi Öğretmenlerinin Sinff Yönetimi Yeterlikleri (Beykoz Örneği) (yüksek lisans tezi, 2012), Marmara Üniversitesi Sosyal Bilimler Enstitüsü, s. 138-139. 
Tablo 29: "Öğrenciyi Tanıma ve İletişim Becerisi” Boyutu “Cinsiyet”e Göre Bağımsız Örneklem T-Testi Sonuçları

\begin{tabular}{|c|c|c|c|c|c|c|c|}
\hline \multirow{3}{*}{$\begin{array}{l}\text { Öğrenciyi Tanıma } \\
\text { ve İletişim Becerisi } \\
\text { Boyutu Toplam Puan } \\
\text { Ortalaması }\end{array}$} & Cinsiyet & $\mathbf{N}$ & $\overline{\mathbf{X}}$ & $S$ & sd & $t$ & $\mathbf{p}$ \\
\hline & Kadın & 211 & 18,44 & 6,69 & \multirow{2}{*}{207,96} & \multirow{2}{*}{2,53} & \multirow{2}{*}{0,012} \\
\hline & Erkek & 120 & 20,25 & 5,42 & & & \\
\hline
\end{tabular}

Yapılan t- testi sonuçlarına göre gözlenen öğretmenlerin sınıf içinde "öğrenciyi tanıma ve iletişim becerisi" boyutu toplam puan ortalamaları "cinsiyet"e göre farklılık göstermektedir. Buna göre araştırmaya katılan erkek öğretmenlerin bu boyuttaki toplam puan ortalama$\operatorname{ları}(\bar{X}=20,25)$ kadın öğretmenlerin toplam puan ortalamalarından $(\bar{X}=18,44)$ yüksektir ve bu farklılaşma istatistiksel olarak da anlamlıdır. [t $(207,96)=2,53 ; \mathrm{p}<0,05]$. Bu sonuçlar, gözlenen erkek öğretmenlerin, kadın öğretmenlere göre öğrencileri ile daha iyi bir iletişim kurduklarını göstermektedir. Bu boyutta cinsiyete bağlı olarak ifade edilen bu farklılaşma, daha önce öğretmenlerin bu alanda kendi cevaplarına dayanılarak yapılmış araştırma sonuçlarına göre farklılık arz etmektedir. Çalışmalardan ikisinde, kadın öğretmenlerin kendilerini erkek öğretmenlere göre bu alanda daha yeterli gördükleri sonucu çıkarken, ${ }^{28}$ diğer çalışmalarda ise cinsiyetler arasında bir farklılaşma sonucu çıkmamıştır. ${ }^{29}$ Araştırmalar arasında çıkan bu farklılık, öğretmenlerin kendi algıları ile dışarıdan yapılan gözlem sonucuna göre, sınıflarında göstermiş oldukları performans arasında fark olduğunu göstermektedir.

Tablo 30: "Öğrenciyi Tanıma ve İletişim Becerisi” Boyutunda "Yaş Gruplarına” Göre Varyansların Homojenliği Testi (Levene)

\begin{tabular}{|c|c|c|c|}
\hline \multirow{2}{*}{ Levene Testi } & İstatistik & Serbestlik Derecesi & $\mathbf{p}$ \\
\cline { 2 - 3 } & 2,36 & 3 & 0,71 \\
\hline
\end{tabular}

Yapılan analizde Levene testinin $\mathrm{p}$ değer 0,05 'den büyük olduğundan $(0,71>0,05)$ varyansların homojen olduğu durumlarda yapılan anova testinin yorumlanmasına geçilebilir.

Tablo 31: “Öğrenciyi Tanıma ve İletişim Becerisi” Boyutu "Yaş Gruplarına” Göre Anova Sonuçları

\begin{tabular}{|c|c|c|c|c|c|c|}
\hline $\begin{array}{c}\text { Varyansın } \\
\text { Kaynağı }\end{array}$ & $\begin{array}{c}\text { Kareler } \\
\text { Toplamı }\end{array}$ & Sd & $\begin{array}{c}\text { Kareler } \\
\text { Ortalaması }\end{array}$ & F & p & Anlamlı Fark \\
\hline Gruplar arası & 267,065 & 3 & 89,022 & 2,52 & $\mathbf{0 , 5 7}$ & \\
\hline Gruplar içi & 11510,645 & 327 & 35,201 & & \\
\hline Toplam & 11777,710 & 330 & & & & \\
\hline
\end{tabular}

28 Koç, "İmam Hatip Lisesi Meslek Dersi Öğretmenlerinin Yeterlikleri Üzerine Bir Araştırma”, s. 152; Koç, “Din Kültürü ve Ahlak Bilgisi Öğretmenlerinin Yeterlikleri”, s. 132.

29 Şimşek, İlköğretim Din Kültürü ve Ahlak Bilgisi Öğretmenlerinin Yeterlikleri (Erzurum Örneği), s. 120; Yazıc1, İlköğretim Din Kültürü ve Ahlak Bilgisi Öğretmenlerinin Yeterlikleri (İstanbul İli Örneği Üzerinde Bir Alan Araştırması), s. 134. 
Tabloda görüleceği üzere yapılan analiz sonucunda $p$ değerinin 0,05 'den büyük olması öğrenciyi tanıma ve iletişim becerisi boyutunda yaş gruplarına göre bir farklılık görülmediği sonucunu ortaya koymaktadır.

Tablo 32: Öğrenciyi Tanıma ve İletişim Boyutu Yeterlik Ortalama Puanlarının Okul Türlerine Göre Betimsel İstatistikleri

\begin{tabular}{|l|c|c|c|}
\hline Okul Türü & $\mathbf{N}$ & $\overline{\mathbf{X}}$ & $\mathbf{S S}$ \\
\hline İlkokul & 14 & 15,78 & 2,29 \\
\hline Orta Okul & 110 & 19,71 & 6,76 \\
\hline İmam Hatip Ortaokulu & 54 & 20,50 & 6,09 \\
\hline Anadolu İHL & 70 & 17,72 & 4,74 \\
\hline Meslek Lisesi & 55 & 18,89 & 6,11 \\
\hline Anadolu Lisesi & 18 & 21,16 & 5,21 \\
\hline Spor Lisesi & 10 & 16,40 & 3,94 \\
\hline Toplam / Ortalama & 331 & 19,09 & 5,97 \\
\hline
\end{tabular}

Tablo 33: "Öğrenciyi Tanıma ve İletişim” Boyutunda "Okul Türlerine” Göre Varyansların Homojenliği Testi

\begin{tabular}{|c|c|c|c|}
\hline \multirow{2}{*}{ Levene Testi } & İstatistik & Serbestlik Derecesi & $\mathbf{p}$ \\
\cline { 2 - 4 } & 2,95 & 6 & 0,008 \\
\hline
\end{tabular}

Yapılan analizde grup varyansların homojen olmadığı tespit edilmiştir. Bu durumlarda yapılan Welch testinin sonuçları ise aşağıdaki gibidir:

Tablo 34: “Öğrenciyi Tanıma ve İletişim” Boyutunda “Okul Türlerine” Göre Welch Testi

\begin{tabular}{|c|c|c|c|}
\hline \multirow{2}{*}{ Welch } & İstatistik & Serbestlik Derecesi & p \\
\cline { 2 - 4 } & 6,025 & 6 & 0,000 \\
\hline
\end{tabular}

Tablo 35: “Öğrenciyi Tanıma ve İletişim” Boyutu “Okul Türleri”ne Göre Dunnett C Testi Sonuçları

\begin{tabular}{|c|c|c|c|}
\hline \multirow{2}{*}{ Dunnett C } & Okul Türü & Ortalamaların Farki & $\mathbf{s x}$ \\
\cline { 2 - 3 } & İlkokul-Ortaokul & $-3,93247^{\star}$ & 0,88 \\
\cline { 2 - 4 } & İlkokul-İHO & $-4,71429^{\star}$ & 1,03 \\
\hline & İlkokul-Anadolu Lisesi & $-5,38095$ & 1,37 \\
\hline
\end{tabular}

Yapılan bu testler sonucunda farklı okul türlerinde çalışan öğretmenlerin arasında öğgrenciyi tanıma ve iletişim boyutu ile ilgili anlamlı farklılık bulunmuştur $(\mathrm{p}<0,05)$. Farklı okul türlerinde çalışan öğretmenler arasındaki farkın tespitinde ise varyansların homojen 
olmadığ durumlarda başvurulan Dunnett $\mathrm{C}$ testinden faydalanılmıştır. Bu testin sonuçlarına göre araştırma sürecinde ilkokullarda derse giren öğretmenlerin $(\overline{\mathrm{x}}=15,78)$; ortao$\operatorname{kul}(\overline{\mathrm{x}}=19,71), \dot{\mathrm{I} H O}(\overline{\mathrm{x}}=17,72)$ ve Anadolu Lisesi’nde $(\overline{\mathrm{x}}=21,16)$ derse gören öğretmenlere kıyasla, iletişim boyutunda daha az puan aldıkları görülmektedir. İlkokullar ile diğer okul türleri arasında oluşan bu farklılığın sebebini, öğretmenlerin 4. sınıfa giden öğrencilerin psikolojik ve fiziksel gelişimleri ile ilgili yeterince bilgi sahibi olmadıkları şeklinde yorumlamak mümkündür. Tabloya göre öğrenciyi tanıma ve iletişim boyutundaki aritmetik ortalamalar, liseden ilköğretime doğru azalma eğilimi göstermektedir. Başka bir deyişle, ilköğretimde din derslerine giren öğretmenler ilkokul çağındaki çocuğun seviyesini ve dilini yakalayamamışlardır.

Bu konuda deneyimlerimiz de bu sonucu desteklemektedir. Öğretmen adayları ile yapılan derslerde, öğretmen adaylarına 9-12 yaş grup çocuklarına hitap eden çizgi/animasyon film karakterlerini tanıyıp tanımadıkları sorulduğunda, öğretmen adaylarının büyük bir kısmı bu karakterleri bilmediğini, bir kısmı ise adını duysa bile hiç izlemediğini belirtmiştir. Hâlbuki öğretmenin bu yaş grubu öğrencilerin hoşlandığı ve takip ettiği kahramanlardan/ karakterlerden ders işlerken faydalanması, en azından onlardan söz etmesi, bildiğini belli etmesi bu yaş grubundaki öğrencilerle öğretmeleri arasındaki iletişimi kuvvetlendiren bir faktör olacaktır. Öğretmenlerin bu yaş grubu ile ortak bir dil oluşturamaması, öğretmen ve öğrenci arasındaki iletişimi olumsuz etkilemektedir.

Öğretmen-öğrenci arasındaki iletişimin kuvvetli olması, başarıyı olumlu yönde etkileyeceğinden, din derslerine giren öğretmenler özellikle küçük yaştaki çocuklarla doğru ve güçlü bir iletişim kurmaya çalışmalıdırlar. Bu iletişim de ancak öğretmenin muhatap olduğu kesimin ilgi alanlarını, yeteneklerini, becerilerini ve ihtiyaçlarını bilmesi ve bunları dikkate alması ile sağlanabilir. Bu sebeple, özellikle ilköğretim ve ortaokullarda derse giren öğretmenlerin çocuklarla doğru bir iletişime girmesi, ileride çocukların zihinlerinde olumlu bir din algısı oluşturmak adına da önem arz etmektedir.

İlkokul seviyesinde derse giren din dersi öğretmenlerinin, iletişim boyutunda daha düşük puanlar alması, din dersi öğretmeni yetiştirme modelinin de tartışılması gerektiğini ortaya koymaktadır. Zira ilahiyat fakültelerinde okuyan din dersi öğretmeni adayları genel bir pedagojik formasyon eğitimi almaktadır. Yaş gruplarına göre öğrencileri ile nasıl iletişime geçecekleri, onlarla hangi materyalleri kullanarak ders yapacakları, hangi yöntem ve teknikleri kullanacakları ile ilgili teorik ve uygulama düzeyinde özel bir eğitim almadan mezun olabilmektedirler. 
Tablo 36: "Öğrenciyi Tanıma ve İletişim Becerisi” Boyutu "Ders İşleme Yöntemi”ne Göre Bağımsız Örneklem T-Testi Sonuçları

\begin{tabular}{|c|c|c|c|c|c|c|c|}
\hline \multirow{3}{*}{$\begin{array}{l}\text { Öğrenciyi } \\
\text { Tanıma ve } \\
\text { İletişim Becerisi } \\
\text { Boyut Toplamı } \\
\text { Ortalaması }\end{array}$} & Öğretim Yöntemi & $\mathbf{N}$ & $\overline{\mathbf{X}}$ & S & sd & $\mathbf{t}$ & $\mathbf{p}$ \\
\hline & Öğretmen Merkezli & 255 & 20,07 & 6,07 & \multirow{2}{*}{173,754} & \multirow{2}{*}{6,81} & \multirow{2}{*}{0,00} \\
\hline & Öğrenci Merkezli & 76 & 15,84 & 4,27 & & & \\
\hline
\end{tabular}

Yapılan analiz, öğretmenin dersi işleme yöntemindeki farklılaşmanın, iletişim becerisi boyutunda anlamlı bir farklılık gösterdiğini ortaya koymaktadır. $[\mathrm{t}(173,754)=6,81 ; \mathrm{p}<0.05$.] Derslerini daha çok öğretmen merkezli işleyen öğretmenlerin ( $\overline{\mathrm{x}}=20,07)$ iletişim becerisi boyutunda öğrenci merkezli işleyenlere $(\overline{\mathrm{x}}=15,84)$ yönelik daha yüksek puan aldıkları görülmektedir. Bu sonuç oldukça dikkat çekicidir. Materyal kullanma boyutunda da benzer şekilde, öğretmen merkezli yöntemleri kullandığı gözlemlenen öğretmenlerin daha yüksek puan aldıkları görülmüştü. Burada da aynı şekilde öğretmen merkezli yöntemleri kullanan öğretmenlerin, öğrenci ile iletişim toplam puanları yüksek çıkmıştır. Bu tabloyu, derslerini öğretmen merkezli yöntemlerle işleyen öğretmenlerin, derslerini tek taraflı yapmadıkları, ders içinde ve dışında öğrencilerle iletişim kurmaya özen gösterdikleri şeklinde yorumlamak mümkündür.

\section{Sonuç ve Öneriler}

Eğitimden istenilen sonuçların alınmasında öğretimin yapıldığı ortam, ders materyalleri gibi unsurların da etkisi olmakla birlikte, bu süreç büyük oranda öğretmenlerin niteliği ile alakalıdır. Öğretmenlere yüklenen roller ve beklentiler onların eğitimiyle de yakından ilişkilidir. Öğretmen niteliğini arttırmanın yolu önce hizmet öncesi eğitimle, sonrasında ise hizmet içi eğitimlerle sağlanabilir.

Din dersi öğretmenlerinin hizmet öncesi eğitimi, ilahiyat fakülteleri bünyesinde yapılmaktadır. Bu bakımdan ilahiyat fakültesi programlarının, bu fakültelerin din dersi öğretmeni de yetiştirdiği göz önüne alınarak, beklenen yeterlik alanlarına dayalı bir şekilde yapılandırılması din dersi öğretmeni niteliğinin arttırılmasında önemli rol oynayacaktır. Benzer şekilde, bu programlarda teorik derslerden çok uygulamalı derslere yer verilmesi öğretmenlerden beklenen yeterliklerin yerine getirilmesi açısından faydalı olacaktır. İlahiyat fakültesi programlarının yenilenmesi yıllardır tartışılagelen konulardan birisi olmasına rağmen, maalesef bu alanda yeterince ilerleme kaydedilememiștir. İlahiyat fakülteleri aynı programla, hem din görevlisi hem de din dersi öğretmeni yetiştirmeye çalışmaktadır. Bu ise beklenen yeterliklerin sağlanması hususunda, bazı aksaklıkları da beraberinde getirmektedir.

Bununla beraber, öğretmenlerin niteliği sadece üniversitede aldıkları eğitimin kalitesi ile ilgili değildir. Hali hazırda görev yapan öğretmenlerin eksik ve geliştirilmeye açık yönlerinin tespit edilmesi, bu anlamda hayati önem arz etmektedir. Zira bir öğretmenin fakültede 
almış olduğu eğitimle, bütün meslek hayatını devam ettirmesi mümkün görünmemektedir. Öğretmen, meslek hayatı boyunca kendisini yeniçağın nesillerine rehber olacak şekilde donatmalıdır. Örneğin, eskiden bilgiyi aktarmak önemli iken, bilgiye ulaşmanın çok kolay olduğu günümüzde, artık öğretmenden beklenen sadece bilgiyi aktarması değil, bilgiye ulaşma yollarını de göstermesidir.

Ülkemizde öğretmen atamaları, adayların Kamu Personeli Seçme Sınavı (KPSS) ve genel olarak öğretmenlik ve alan sınavı puanlarına ve daha sonra girdikleri mülakat sınav notlarına göre yapılmaktadır. Atamadan sonraki süreçte ise, öğretmenlerin yeterliklerini ölçmeye, eksik ve tam yönlerini tespit etmeye yönelik herhangi bir performans değerlendirmesi yapılmamaktadır. Bu durum ise, öğretmenlerin genel ve özel hangi alanlarda iyi ve hangi alanlarda eksik olduklarının ortaya koyulamamasına sebep olmaktadır. Eksiklikler ortaya koyulmadığında, öğretmen yeterliklerin arttırılması çabaları da noksan kalmaktadır.

Okullarda verilen eğitimin, öğretmen nitelikleri ile paralel olduğu göz önüne alınırsa, bu eksikliklerin tespit edilip geliştirilmesinin önemi kendiliğinden ortaya çıkacaktır. Öğretmenlik Mesleği Genel Yeterliklerine yönelik yapılacak performans değerlendirmeleri, öğretmenlerin güçlü olan taraflarını ortaya koymasının yanında, alanda var olan eksikliklerin gerçekçi bir şekilde ortaya konulması ve bu doğrultuda hizmet içi eğitim çalışmaları içinde yol gösterici bir kılavuz görevi görmesi bakımından önem arz etmektedir.

Din derslerine giren öğretmenlerin sınıf ortamında gözlemlenebilen yeterliklerini ortaya koymak amacıyla yapılan bu araştırma göstermektedir ki, öğretmenlerin öğrenme-öğretme boyutu yeterlikleri aritmetik ortalaması 2,31 olup "az düzey"dedir. Bu boyutta öğretmenin derse girerken motivasyonu sağlamak amacıyla dikkat çekici bir giriş yapması, dersi işlerken düşünmeye sevk eden sorular sorması ve dersin sonunda öğrettiklerini kontrol etmesi (bu üç gösterge orta düzeydedir) ve öğrencilerle göz iletişimi kurması (hiç düzeyinde) haricindeki bütün yeterlik göstergeleri az düzeyde çıkmıştır. Bu boyutta yer alan yeterliklere sahip olma ile cinsiyet arasında istatistiksel olarak anlamlı bir fark bulunmazken, yaş grupları, görev yapılan okul türü ve dersi işleme yöntemleri arasındaki farklar anlamlı bulunmuştur. Buna göre, 50-59 yaş aralığındaki öğretmenlerin 20-29 ve 30-39 yaş aralı̆̆ındaki öğretmenlere nazaran, bu alandaki yeterliklere daha fazla sahip oldukları gözlemlenmiștir. Aynı şekilde İHO'da çalışan öğretmenlerin ilköğretimde çalışanlara ve öğretmen merkezli ders işleyenlerin de öğrenci merkezli ders işleyenlere kıyasla, bu boyuttaki yeterliklere daha fazla sahip oldukları görülmektedir.

Araştırmada, öğretmenlerin en fazla sahip oldukları boyutun materyal kullanma boyutu olduğu görülmektedir. Öğretmenlerin materyal kullanma boyutu yeterlikleri aritmetik ortalaması 3,71 olup "oldukça düzey"indedir. Bu boyutta çalışılan okul türleri arasında anlamlı bir farklılık görülmezken, erkek öğretmenlerin kadın öğretmenlere, derslerini öğretmen merkezli işleyenlerin öğrenci merkezli işleyenlere oranla bu alandaki yeterliklere daha 
fazla sahip oldukları görülmektedir. Aynı şekilde yaş faktörü de bu alanda anlamlı bir farklılık oluşturmaktadır. Öğretmenlerin yaşları arttıkça materyal kullanma yeterlikleri de artmaktadır.

Araştırmada gözlemlenen son boyut öğrenciyi tanıma ve iletişim boyutudur. Öğretmenlerin öğrenciyi tanıma ve iletişim becerisi boyutu aritmetik ortalamaları 2,38 olup yeterlik düzeyleri "az" seviyesindedir. Bu boyutta karşılaşılan en dikkat çekici sonuçlardan birisi gözlem sonucunda öğretmenlerin öğretmenlik mesleğini severek yapıp yapmadıkları $(1,85)$ ve öğrencileri arasında adil davranıp davranmadıkları $(1,86)$ ile ilgili yeterlik göstergeleridir. Öğretmenlerin bu iki yeterlik göstergesinden oldukça düşük seviyede puan almaları, hem üzücü hem de düşündürücüdür. Bu boyutta öğretmenlerin yaşları arasında anlamlı bir farklllık görülmezken, erkek öğretmenlerin kadın öğretmenlere; derslerini öğretmen merkezli ders işleyenlerin öğrenci merkezli işleyenlere oranla bu alandaki yeterliklere daha fazla sahip oldukları görülmektedir. Bu boyutta çalışılan okul türleri arasında da anlamlı bir farklılık vardır. İlkokullarda çalışan öğretmenlerin bu boyutta, diğer okul türlerine göre daha az yeterliğe sahip oldukları görülmektedir.

Yukarıda zikredilen araştırma sonuçları, din derslerine giren öğretmenlerin sınıf içinde gözlemlendiklerinde "öğrenme-öğretme", "materyal kullanma" ve "öğrenciyi tanıma ve iletişim becerisi” boyutlarında gösterdikleri yeterlik düzeylerini göstermektedir. Söz konusu yeterlik düzeyleri, daha önce yapılan ve öğretmenlerin kendi yeterlik algılama düzeylerini gösteren çalışma sonuçlarından farklılık arz etmektedir. Bu farklılık, öğretmenlerin kendi yeterlik düzeyi algıları ile dışarıdan gözlenen yeterlik düzeyi arasındaki farkı ortaya koymaktadır. Bu farklılık, öğretmenlerin yeterlik düzeylerinin ölçülmesinde kendilerinden başka kaynaklardan da faydalanılması gerektiğini ortaya koymaktadır. Farklı kaynaklardan elde edilen bilgiler, öğretmenlerin yeterlik boyutlarında kendilerini daha iyi tanımalarına imkân verecektir. Bu veriler hem öğretmenlerin kendilerine, hem hizmet içi eğitim programlarının düzenleyicilerine, hem de öğretmen yetiştiren kurumlara önemli bir rehber konumunda olacaktır. Bu veriler sayesinde, öğretmenler eksik ve geliştirilmesi gereken yönlerini daha doğru görebilecek ve kendilerini bu doğrultuda geliştirebileceklerdir.

Öğretmenlerin kendi algıları önemli olmakla birlikte, bunu tek başına bir değerlendirme ölçütü olarak kabul etmek yeterli değildir. Bu bakımdan, öğretmenlerin mesleki ve alan yeterliklerini ortaya koymak adına MEB tarafından yapılacak değerlendirmelerin öğrencileri, meslektaşları, okul idarecileri, veliler gibi farklı bakış açılarını da içine alacak şekilde yapılması daha objektif sonuçlar verecektir. Bu sonuçlar doğrultusunda yapılacak iyileştirmelerin, öğretmen niteliğini arttırıcı sonuçlar vermesi ise istenen ve beklenen bir sonuçtur. 


\section{Kaynakça}

Acuner, Hacı Yusuf - Erbaş, Ahmet Akif. “Din Kültürü ve Ahlak Bilgisi ve Diğer Branş Öğretmenlerine Göre Din Kültürü ve Ahlak Bilgisi Öğretmenlerinin Yeterlikleri”. Din Bilimleri Akademik Araştırma Dergisi, sy. 16/1, 2016, s. 147-170.

Akyürek, Süleyman. İlköğretim Din Kültürü ve Ahlak Bilgisi Öğretmen Adaylarının Yeterlilikleri (Kayseri örneği). Kayseri: Laçin Yayınları, 2008.

-------. "Din Kültürü ve Ahlak Bilgisi Öğretmenlerinin Öğrenme-Öğretme Sürecine İlişkin Yeterlikleri.” Türkiye’de Okullarda Din Öğretimi (ed. Recep Kaymakcan, Mahmut Zengin, Z. Şeyma Arslan). İstanbul: DEM Yayınları, 2011, s. 491-522.

-------. "İmam Hatip Lisesi Meslek Dersi ile Din Kültürü ve Ahlak Bilgisi Öğretmenlerinin EğitimÖğretim Yeterliklerine İlişkin Algılar”. Değerler Eğitimi Dergisi, 10/23, Haziran 2012, s. 7-45.

Arpac1, Mücahit. İlköğretim Din Kültürü ve Ahlak Bilgisi Öğretmenlerinin Yeterlikleri (İzmir İli Örneğinde Bir Alan Araştırması) (yüksek lisans tezi, 2004). Ankara Üniversitesi Sosyal Bilimler Enstitüsü.

Asri, Safinaz. Din Kültürü ve Ahlak Bilgisi Öğretmenlerinin Mesleki Yeterlikleri (Göller Bölgesi Örneği) (yüksek lisans tezi, 2005). Süleyman Demirel Üniversitesi Sosyal Bilimler Enstitüsü.

Aşıkoğlu, Nevzat Yaşar. “Din Öğretiminde Öğretmenin Rolü ve Din Dersi Öğretmeni Yeterlilikleri (Türkiye Örneği)”. C. Ü. İlahiyat Fakültesi Dergisi, XV/1, 2011, s. 5-13.

Aydın, Muhammet Şevki. Cumhuriyet Döneminde Din Eğitimi Öğretmeni Yetiştirme ve İstihdamı (19231950). İstanbul: DEM Yayınları, 2016.

-----. Din Kültürü ve Ahlak Bilgisi Öğretmenlerinin Pedagojik Formasyon Yeterlikleri (doktora tezi 1992). Erciyes Üniversitesi Sosyal Bilimler Enstitüsü.

Büyüköztürk, Şener. Sosyal Bilimler İçin Veri Analizi El Kitabı. Ankara: Pegem Akademi 2017.

Can, Abdullah. SPSS ile Bilimsel Araştırma Sürecinde Nicel Veri Analizi. Ankara: Pegem Akademi 2016.

Cebeci, Suat. Imam-Hatip Lisesi Meslek Dersleri Öğretmenlerinin Yeterlilikleri (doktora tezi 1994). Ankara Üniversitesi Sosyal Bilimler Enstitüsü.

Doğan, Recai - Altaş, Nurullah. “İlköğretim Din Kültürü ve Ahlak Bilgisi Öğretmenlerinin Yeterlik Düzeyini Belirleyen Faktörler (Ankara Örneği)”. Ankara Üniversitesi İlahiyat Fakültesi Dergisi, XLIV/2, 2003, s. 173-186.

------- "İlköğretim Din Kültürü ve Ahlak Bilgisi Öğretmenlerinin Yeterlik Ölçeği Üzerine Bir Ön Araştırma”. Ankara Üniversitesi İlahiyat Fakültesi Dergisi, XLIII/1, 2002, s. 109-122.

Durmuş, Beril - Çinko, Murat - Yurtkoru, E. Serra. Sosyal Bilimlerde SPSS'le Veri Analizi. İstanbul: Beta Yayınlar1 2016.

Erbaş, Ahmet Akif. Din Kültürü ve Ahlak Bilgisi Öğretmenlerinden Beklenen Yeterlikler Üzerine Yeni Öğretmen Yetiştirme Modeli Bağlamında Bir Araştırma (yüksek lisans tezi 2015). Recep Tayyip Erdoğan Üniversitesi Sosyal Bilimler Enstitüsü.

Ev, Halit. “İlköğretim Din Kültürü ve Ahlak Bilgisi Dersi Öğretmenlerinin Yöntemler Konusundaki Yeterlilikleri ile İlgili Öğretmen Adaylarının Görüşleri”. Din Kültürü ve Ahlak Bilgisi Çalışma Toplantısı I. (haz. Z. Şeyma Arslan) İstanbul: DEM Yayınları, 2004, s. 95-118.

Fakioğlu Bağcl, Hatice. İlköğretim Din Kültürü ve Ahlak Bilgisi Öğretmenlerinin Sinıf Yönetimi Yeterlikleri (Beykoz Örneği) (yüksek lisans tezi 2012). Marmara Üniversitesi Sosyal Bilimler Enstitüsü.

Gökçe, Erten. İlköğretim Öğretmenlerinin Yeterlikleri (doktora tezi 2006). Ankara Üniversitesi Sosyal Bilimler Enstitüsü. 
Gündoğdu, Yusuf Bahri. İlköğretim Din Kültürü ve Ahlak Bilgisi Öğretmenlerinin Öğrenci Başarısını Değerlendirme Yeterlikleri: İstanbul Örneği (doktora tezi 2011). İstanbul Üniversitesi Sosyal Bilimler Enstitüsü.

Güneş, Ahmet Melih - Buluç, Bekir. "Sınıf Öğretmenlerinin Teknoloji Kullanımları ve Öz Yeterlilik İnançları Arasındaki İlişki”. TÜBAV Bilim Dergisi, 10/1, 2017, s. 94-113.

Işıkdoğan, Davut. İlköğretim Din Kültürü Ve Ahlak Bilgisi Öğretmenliği Bölümü Mezunu Öğretmenlerin Yeterlikleri (doktora tezi 2006). Ankara Üniversitesi Sosyal Bilimler Enstitüsü.

Karasar, Niyazi. Bilimsel Araştırma Yöntemi. Ankara: Nobel Yayınları, 1994.

Kars, Yunus Emre. Din Kültürü ve Ahlak Bilgisi Öğretmenlerinin Kendi Algılarına Dayalı Sinıf Yönetimi Yeterlikleri (Konak İlçesi Örneği) (yüksek lisans tezi 2007). Dokuz Eylül Üniversitesi Sosyal Bilimler Enstitüsü.

Koç, Ahmet. "Din Kültürü ve Ahlak Bilgisi Öğretmenlerinin Yeterlikleri”. Değerler Eğitimi Dergisi, 8/19, Haziran 2010, s. 107-149.

----- “Din Kültürü ve Ahlak Bilgisi Öğretmenlerinin Öğrenme-Öğretme Sürecine İlişkin Yeterlikleri.” Türkiyede Okullarda Din Öğretimi (ed. Recep Kaymakcan, Mahmut Zengin, Z. Şeyma Arslan) İstanbul: DEM Yayınları, 2011, s. 523-553.

-------. “İmam Hatip Lisesi Meslek Dersi Öğretmenlerinin Yeterlikleri Üzerine Bir Araştırma”. C.Ü. İlahiyat Fakültesi Dergisi, XIII/2, 2009, s. 131-174.

MEB, Öğretmenlik Mesleği Genel Yeterlikleri. Öğretmen Yetiştirme ve Geliştirme Genel Müdürlüğü, Ankara 2017.

MEB, Öğretmenlik Mesleği Genel Yeterlikleri. Öğretmen Yetiștirme ve Eğitimi Genel Müdürlüğü, Ankara 2006.

Milli Eğitim Temel Kanunu, Md 43.

Milli Eğitim Bakanlı̆̆ı Tebliğler Dergisi, Kasım 2006-2590, Ankara.

Şimşek, Eyüp. İlköğretim Din Kültürü ve Ahlak Bilgisi Öğretmenlerinin Yeterlikleri (Erzurum Örneği) (doktora tezi 2006). Atatürk Üniversitesi Sosyal Bilimler Enstitüsü.

Taşçı, Cuma. İmam Hatip Liselerinde Meslek Dersi Öğretiminin Yeterlik Durumu ve Meslek Dersleri Ögrretmenlerinin Temel Yeterliklere Sahip Olma Düzeyleri (yüksek lisans tezi 2006). Ankara Üniversitesi Sosyal Bilimler Enstitüsü.

Turan, E. Zehra. “Din Kültürü ve Ahlak Bilgisi Öğretmen Yeterlikleri: Veli Beklentileri”. Çukurova Üniversitesi İlahiyat Fakültesi Dergisi, 17/2, 2017, s. 185-204.

Uçar, Recep. İlköğretim Okulu II. Kademedeki Din Kültürü ve Ahlak Bilgisi Öğretmenlerinin Sinıf Yönetimi Yeterlikleri (Kayseri İl Merkezi Örneği) (doktora tezi 2004). Erciyes Üniversitesi Sosyal Bilimler Enstitüsü.

Uysal, Bekir. Din Kültürü ve Ahlak Bilgisi Öğretmenlerinin Beden Dilini Kullanma Yeterlilik Düzeyi: Tuzla Örneği (yüksek lisans tezi 2013). Necmettin Erbakan Üniversitesi Sosyal Bilimler Enstitüsü.

Üzümcü, Muzaffer. Din Kültürü ve Ahlak Bilgisi Öğretmenlerinin Kaynaştırma Eğitimine İlişkin Yeterlikleri, Sorunları ve Beklentileri Üzerine Bir Araştırma (doktora tezi 2016). Recep Tayyip Erdoğan Üniversitesi Sosyal Bilimler Enstitüsü.

Yazıcı, Işı1. İlköğretim Din Kültürü ve Ahlak Bilgisi Öğretmenlerinin Yeterlikleri (İstanbul İli Örneği Üzerinde Bir Alan Araştırması) (yüksek lisans tezi 2004). Ankara Üniversitesi Sosyal Bilimler Enstitüsü.

Zengin, Mahmut. “Din Kültürü ve Ahlak Bilgisi Öğretmenlerinin Eğitim Öğretim Yeterlik Algıları”. Sakarya İlahiyat Fakültesi Dergisi, XV/27, 2013/1, s. 2-28. 